\title{
ВЛИЯНИЕ ВЫСОКОВОЛЬТНЫХ ИМПУЛЬСНЫХ РАЗРЯДОВ НА ПОВЕРХНОСТНОЕ НАТЯЖЕНИЕ РАСПЛАВЛЕННЫХ СОЛЕЙ
}

\author{
Джамалова Светлана Аличубановна \\ ГАОУ ВО «Дагестанский государственный \\ университет народного хозяйства» \\ ФГБОУ ВО «Дагестанский государственный университет»
}

Аннотация. В данной статье рассматриваются систематические исследования влияния ВИР на поверхностное натяжение расплавленных бинарных смесей. Поэтому нами предложен и использован фотоэлектрический метод регистрации разности уровней жидкости в манометре. Чувствительность установки при этом увеличивается более чем в 5 раз.

После подачи высоковольтных импульсов поверхностное натяжение, $\gamma$, уменьшается. Чем больше амплитуда импульсного напряжения, тем меньше $\gamma$ и тем больше относительное изменение коэффициента поверхностного натяжения.

Ключевые слова: высоковольтные импульсные разряды, поверхностное натяжение, расплавы, щелочные металлы, щелочноземельые металлы, проводимость, релаксация, аргон.

\section{EFFECT OF HIGH-VOLTAGE PULSE DISCHARGES ON THE SURFACE TENSION OF MOLTEN SALTS}

\author{
Dzhamalova Svetlana Alichubanovna \\ Dagestan State University of National Economy, \\ Dagestan State University
}

\begin{abstract}
This article discusses systematic studies of the effect of VIR on the surface tension of molten binary mixtures. Therefore, we have proposed and used a photoelectric method for registering the difference in liquid levels in the pressure gauge. At the same time, the sensitivity of the installation increases by more than 5 times.
\end{abstract}


After the high-voltage pulses are applied, the surface tension, decreases. The greater the amplitude of the pulse voltage, the smaller and the greater the relative change in the surface tension coefficient.

Key words: high-voltage pulsed discharges, surface tension, melts, alkali metals, alkaline earth metals, conductivity, relaxation, argon.

Одним из направлений создания новых технологий является исследование влияния воздействия внешних возмущений (электрических, магнитных, акустических и других полей) на строение и свойства систем, служащих реакционными средами. Высоковольтные исследования солевых расплавов и твердых электролитов показали, что с ростом напряженности электрического поля их проводимость возрастает, достигая предельных значений в зависимости от рода электролита и температуры. Так, в работах $[1,2]$ показано, что проводимость промышленных электролитов для производства алюминия и магния в полях порядка $10^{6} \mathrm{~B} / \mathrm{M}$ возрастает на 100 и более \%. Для возможного практического применения необходимо такие исследования направить на изучение влияния высоковольтных импульсных разрядов (ВИР) и на другие физико-химические свойства расплавленных солей как плотность, поверхностное натяжение, вязкость, масс - перенос и т.д. Начато систематические исследования влияния ВИР на поверхностное натяжение расплавленных солевых систем. При такой скорости подачи инертного газа получаются хорошо воспроизводимые результаты. Величину максимального давления определяли с помощью водяного манометра. Предварительно рабочий газ нагревался до температуры расплава.

В целях увеличения чувствительности такой установки обычно применяют тонкостенные капилляры с малым внутренним диаметром или используют наклонные манометры. Измерение разности уровней жидкости в манометре в момент отрыва пузырька проводят визуально с помощью катетометров. Эта методика измерения разности уровней жидкости в манометре становится довольно трудоемкой при изучении кинетики изменения поверхностного натяжения расплавов во времени после ВИР. Поэтому нами предложен и использован фотоэлектрический метод регистрации разности уровней жидкости в манометре. Чувствительность установки при этом увеличивается более чем в 5 раз (рис.1). 


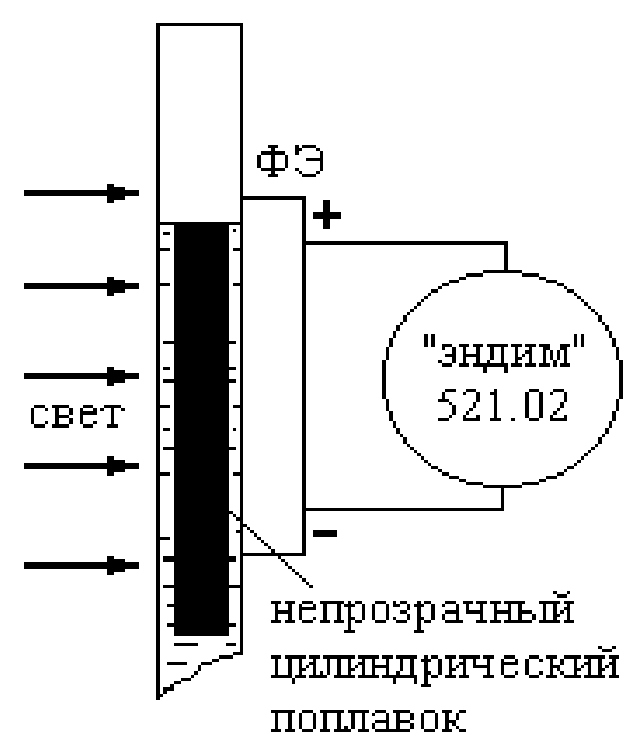

\section{Рис. 1. Фотоэлектрический метод регистрации разности уровней жидкости в манометре}

Кремниевый фотоэлемент ФЭ укреплялся за коленом манометра, сообщающегося с атмосферой. Поверхность фотоэлемента плотно закрывалась черной бумагой с прорезью вдоль трубки шириной 2 мм. Фотоэлемент освещался светом от теневого проектора. Фотоэдс фиксировался самописцем “Эндим” 621.02.

По мере поднятия уровня жидкости в колене манометра, вследствие увеличения давления в газовом пузырьке, фотоэдс увеличивается, так как площадь открытой части фотоэлемента увеличивается. Количество воды в манометре регулировалось таким образом, чтобы при нулевой разности уровней верхний край поплавка совпадал с верхним краем открытой части фотоэлемента. Фотоэдс в этом случае будет равна нулю. По мере увеличения давления в газовом пузырьке поплавок опускается вниз, открывая фотоэлемент. Градуировка установки при одном и том же световом потоке производилась по коэффициентам поверхностного натяжения дистиллированной воды и индивидуальных расплавов, взятых из [3]. Высоковольтные электроды находились на уровне середины расплава. Капилляр находился на глубине 0,5 мм от поверхности расплава.

Исследовано влияние ВИР на поверхностное натяжение расплавленных бинарных смесей: $\mathrm{KCI}-\mathrm{CaCI}_{2}\left(25\right.$ моль.\% $\left.\mathrm{CaCI}_{2}\right)$ при 1044, $1079 \mathrm{~K}$, (50 моль.\% $\left.\mathrm{CaCI}_{2}\right)$ при $1115 \mathrm{~K} ;\left(75\right.$ моль.\% $\left.\mathrm{CaCI}_{2}\right)$ при $1038 \mathrm{~K}$; KCI-SrCI $2\left(25\right.$ моль.\% $\left.\mathrm{SrCI}_{2}\right)$ 
при 968, $1126 \mathrm{~K},\left(50\right.$ моль.\% $\left.\mathrm{SrCI}_{2}\right)$ при 1104, $1130 \mathrm{~K}$; (75 моль.\% $\left.\mathrm{SrCI}_{2}\right)$ при 1067, 1096, $1123 \mathrm{~K}$; КСІ-ВаCI 2 (25 мол.\%) при 1123 К, (50 мол.\%) при 1052 К, (75 мол.\%) при 1038, 1066 К.

При изучении влияния сильных электрических импульсных полей (СЭП) на коэффициент поверхностного натяжения $\gamma$ вначале измерялась эта величина до приложения к расплаву импульсного высокого напряжения, затем подавался импульс напряжения длительностью $\sim 10^{-6}$ с определенной амплитуды напряжения. После подачи импульса прослеживалось изменение коэффициента поверхностного натяжения во времени. Градуировка установки осуществлялась по поверхностному натяжению дистиллированной воды и проверялась по поверхностному натяжению соответствующих не активированных расплавов по [4]. Поток газа (аргона) регулировался таким образом, чтобы в течение одной минуты образовывались не более двух пузырьков. При такой скорости подачи инертного газа получаются хорошо воспроизводимые результаты.

Полученные экспериментальные результаты для исследованных расплавов приведены на рисунках 2-16.

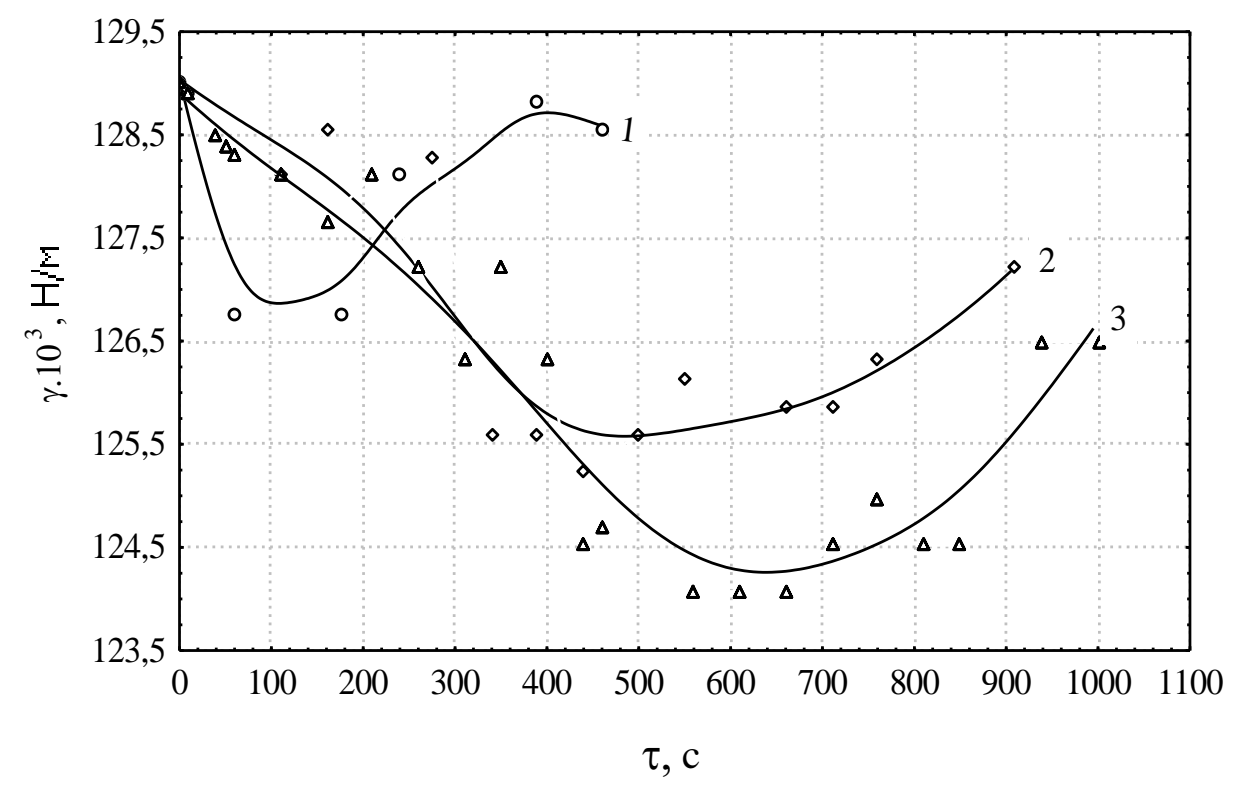

Рис. 2. Изменение поверхностного натяжения $\mathrm{KCI}-\mathrm{CaCI}_{2}(25$ мол.\% СаCI $)$ во времени после ВИР при 1044 К $\left(\gamma_{0}=129,0 \cdot 10^{3} \mathrm{H} / \mathrm{M}\right)$ : $1-2,4$ кB; 2 - 5,5 кB; 3- 6,5 кB 


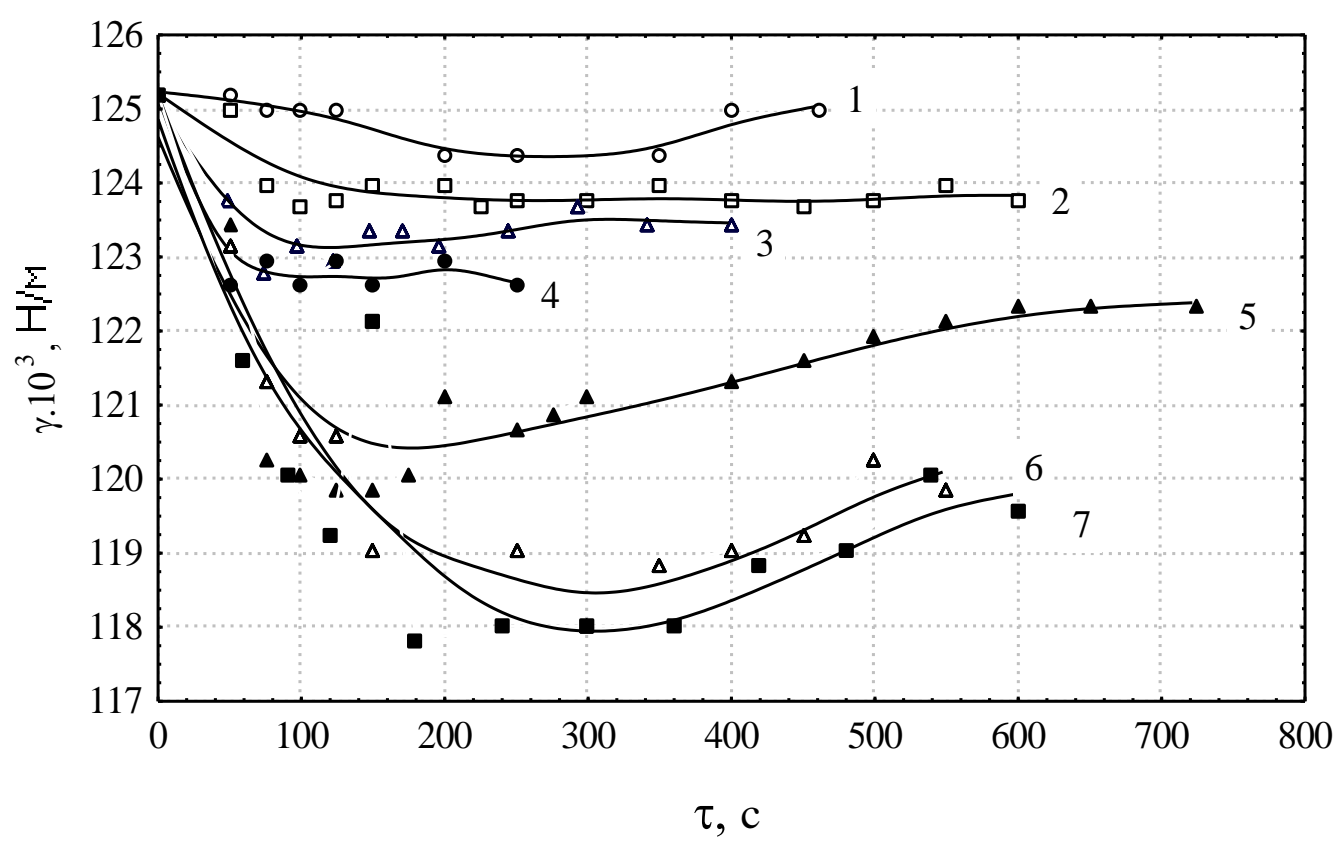

Рис.3. Изменение поверхностного натяжения КCI-CaCI 2 (25 мол.\% СаCI 2 ) во времени после ВИР при 1079 К $\left(\gamma_{0}=125,20 \cdot 10^{3} \mathrm{H} / \mathrm{M}\right)$ :

1-2,0 кB; 2 - 3,1 кB; 3 - 3,6 кB; 4 - 4,7 кB; 5 - 5,2 кB; 6 - 6,4 кВ; 7 - 7,0 кВ

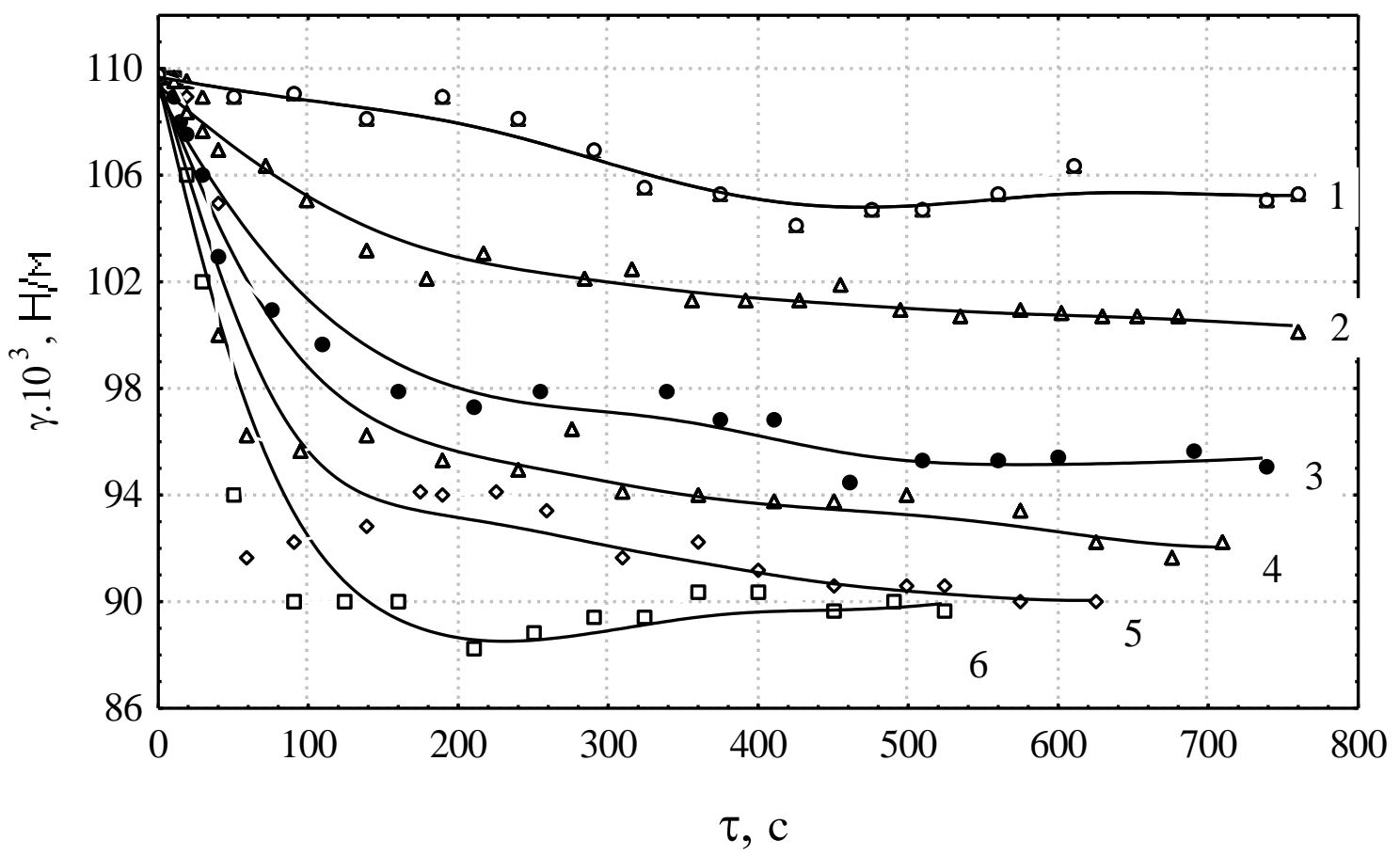

Рис. 4. Изменение поверхностного натяжения КСI-CaCI $2\left(50\right.$ мол.\% $\left.\mathrm{CaCI}_{2}\right)$ во времени после ВИР при 1115 К $\left(\gamma_{0}=109,80 \cdot 10^{3} \mathrm{H} / \mathrm{M}\right): 1$ - 1,5 кВ; 2 - 3,0 кВ;3 - 4,0 кВ; 4 - 5,0 кВ; 5 - 6,0 кВ; 6 - 7,0 кВ 


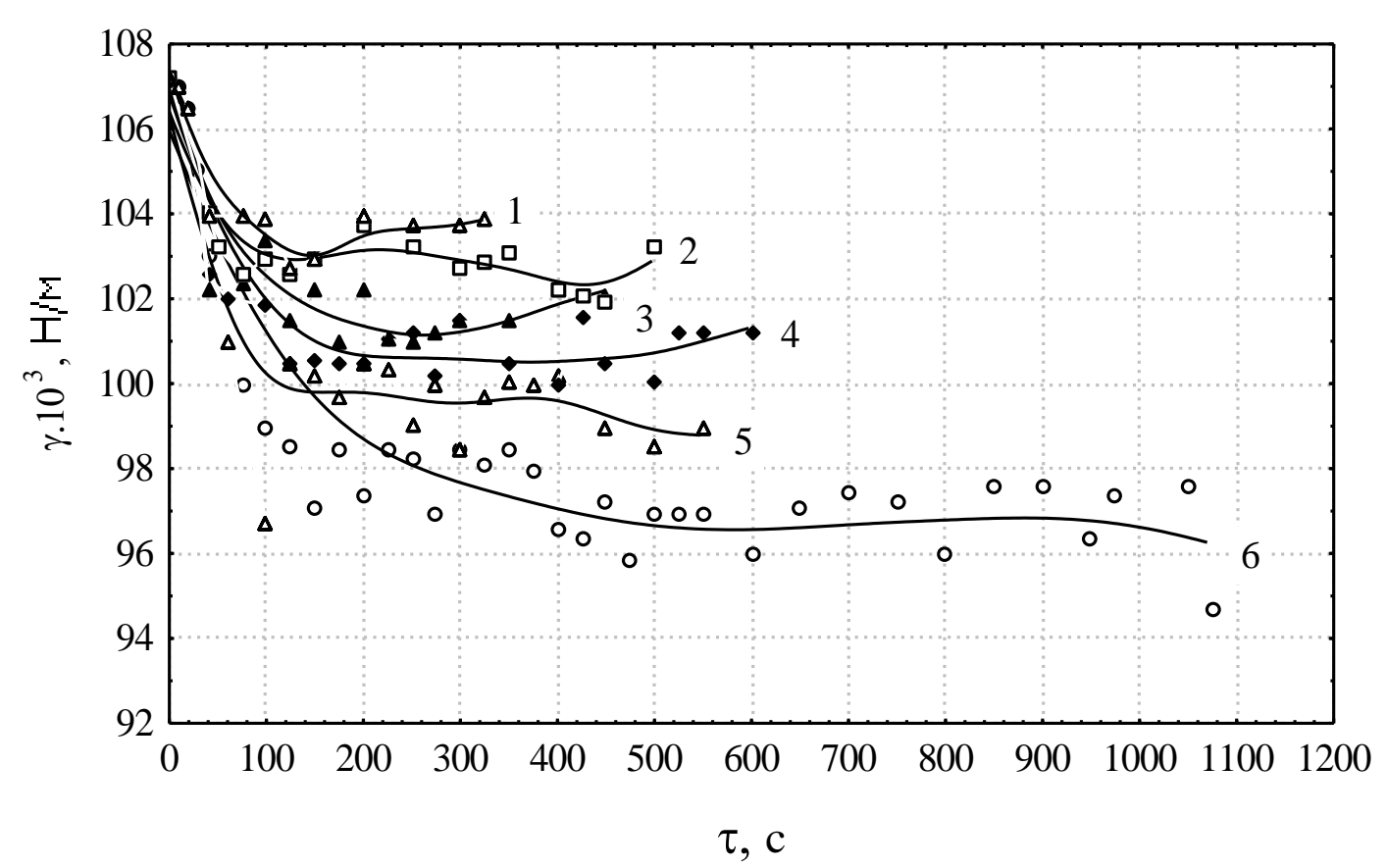

Рис. 5. Изменение поверхностного натяжения КСІ-СaCI 2 (75 мол.\% СаСІ 2 ) во времени после ВИР при 1038 К $\left(\gamma_{0}=107,20 \cdot 10^{3} \mathrm{H} / \mathrm{M}\right)$ :

1 - 2,8 кB; 2 - 4,8 кB;3 - 5,7 кB; 4 - 6,7 кB; 5 - 7,5 кB; 6 - 9 кВ

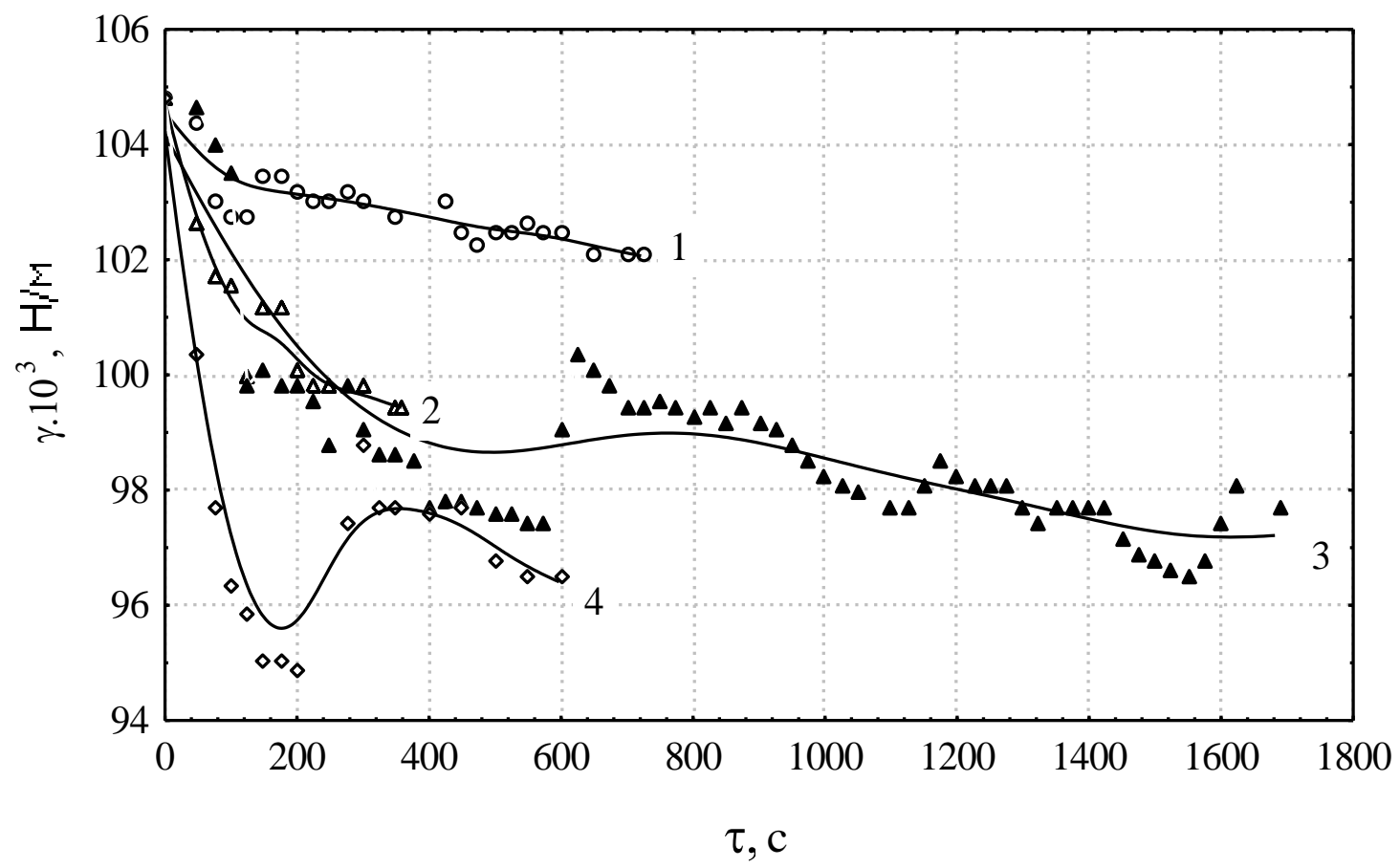

Рис. 6. Изменение поверхностного натяжения КСI-CaCI 2 (75 мол.\% $\left.\mathrm{CaCI}_{2}\right)$ во времени после ВИР при 1071 К $\left(\gamma_{0}=104,80 \cdot 10^{3} \mathrm{H} / \mathrm{M}\right)$ :

$$
1 \text { - 1,5 кB; } 2 \text { - 2,3 кB;3 - 3,4 кB; } 4 \text { - 4,6 кB }
$$




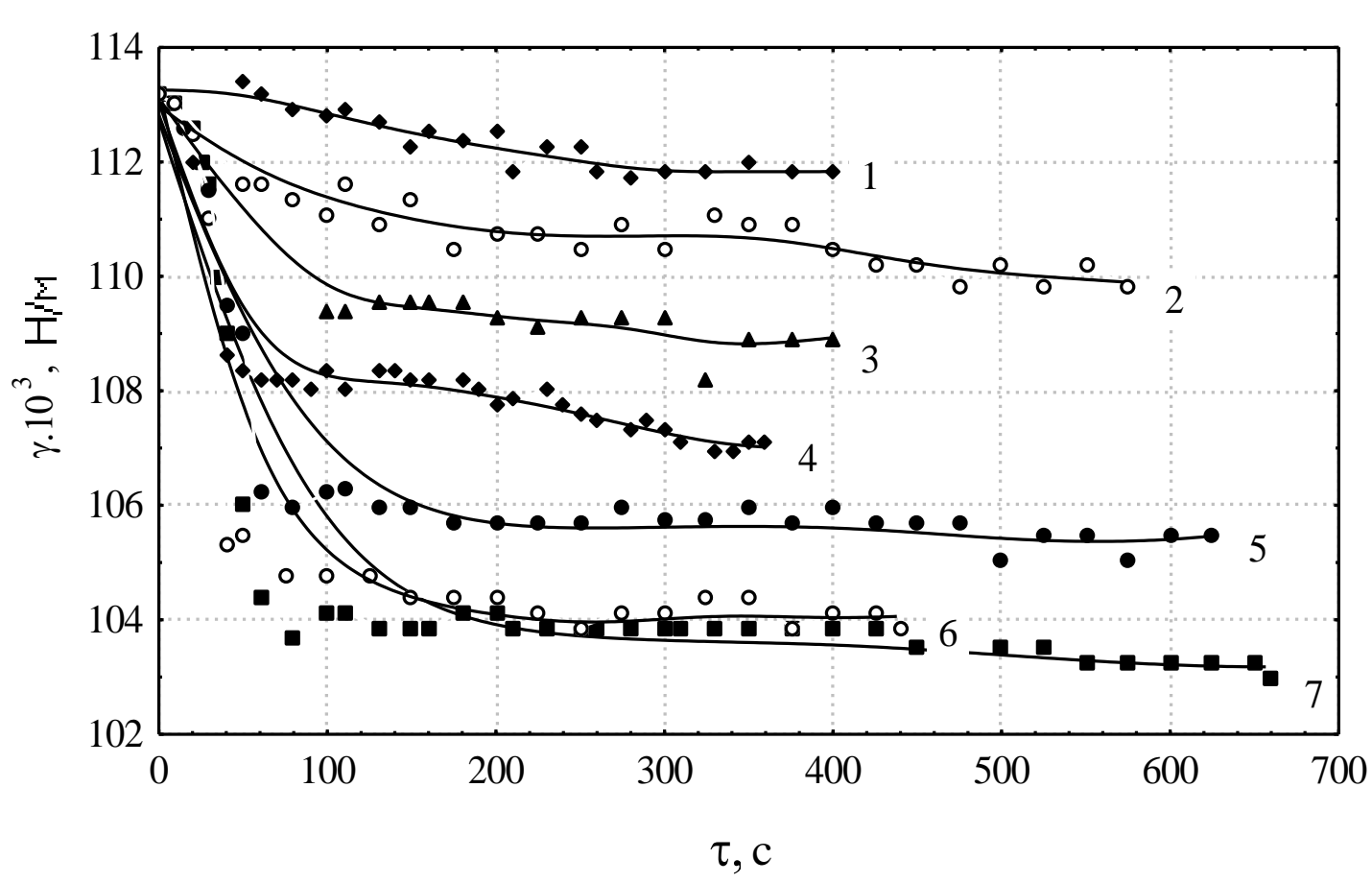

Рис. 7. Изменение поверхностного натяжения KCI-SrCI 2 (25 мол.\% $\left.\mathrm{SrCI}_{2}\right)$ во времени после ВИР при 968 К $\left(\gamma_{0}=113,16 \cdot 10^{3} \mathrm{H} / \mathrm{M}\right)$ :

1 - 2,0 кB; 2 - 3,1 кB; 3 - 5,0 кB; 4 - 6,0 кB; 5 - 7,0 кB; 6 - 7,8 кB; 7 - 9,0 кВ

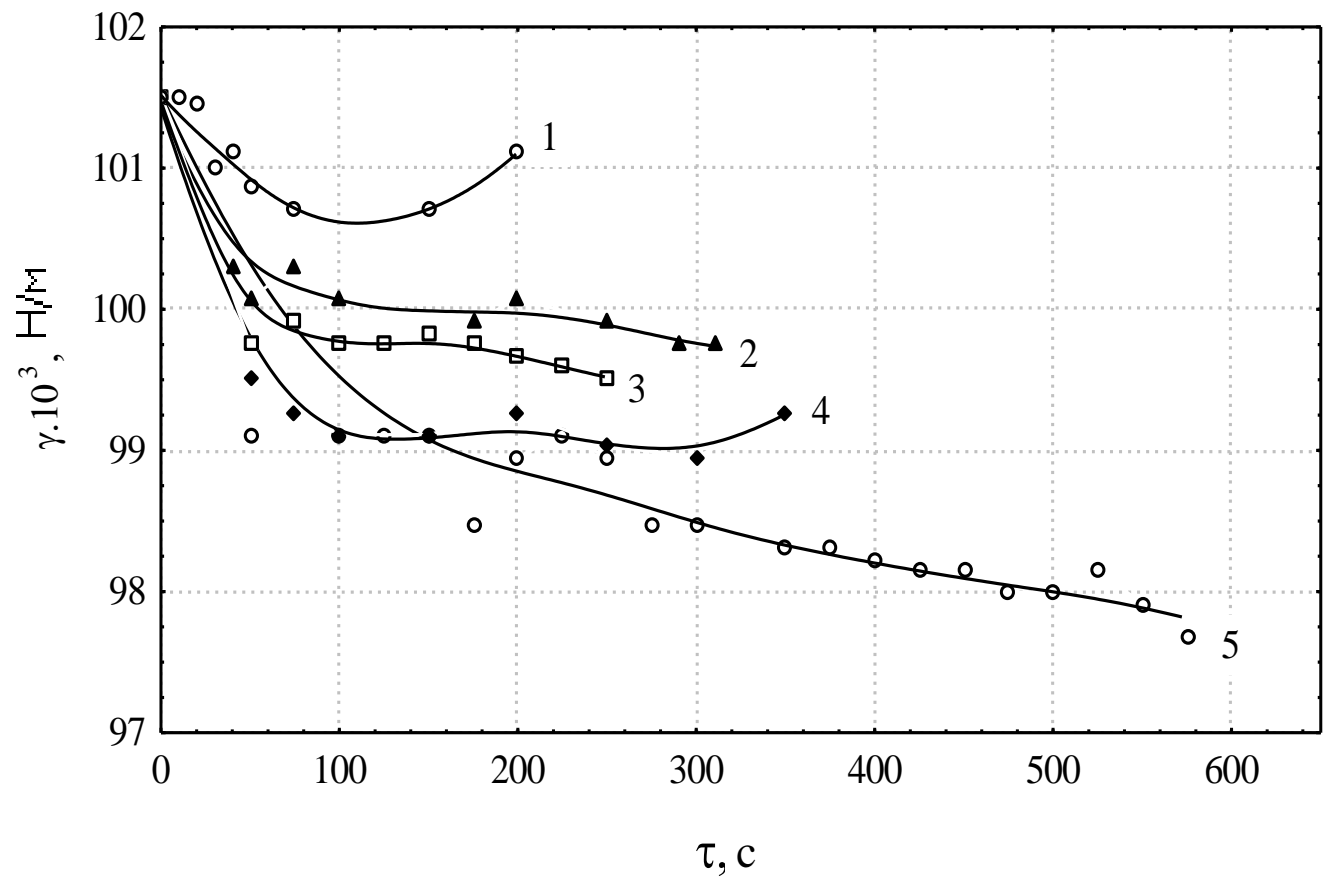

Рис. 8. Изменение поверхностного натяжения $\mathrm{KCI}-\mathrm{SrCI}_{2}\left(25\right.$ мол.\% $\left.\mathrm{SrCI}_{2}\right)$ во времени после ВИР при 1126 К $\left(\gamma_{0}=101,51 \cdot 10^{3} \mathrm{H} / \mathrm{M}\right)$ : 1 - 1,0 кВ; 2 - 3,1 кB; 3 - 5,6 кB; 4 - 6,2 кB; 5 - 9,4 кВ 


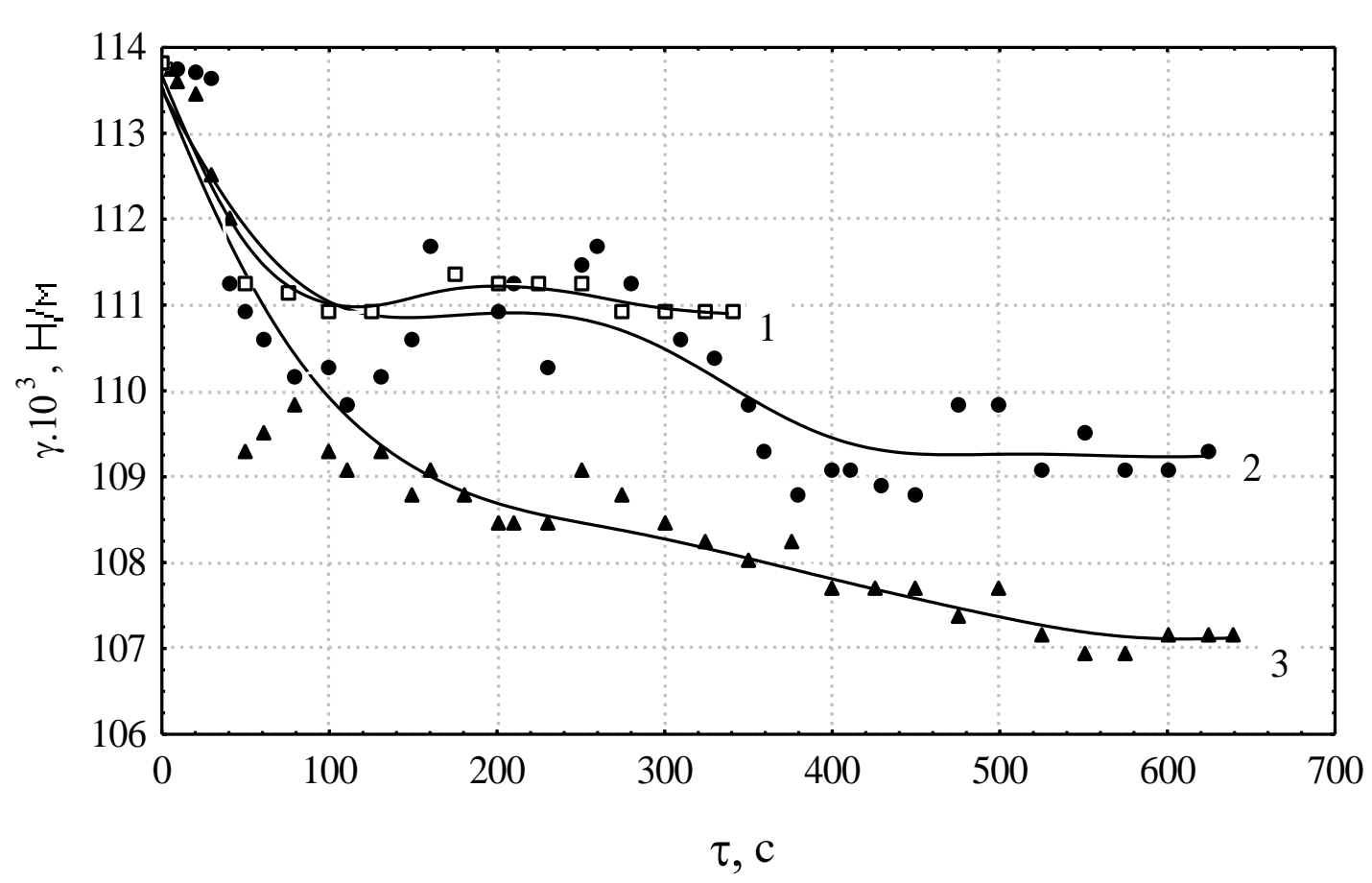

Рис. 9. Изменение поверхностного натяжения $\mathrm{KCI}-\mathrm{SrCI}_{2}\left(50\right.$ мол.\% $\left.\mathrm{SrCI}_{2}\right)$ во времени после ВИР при 1104 К $\left(\gamma_{0}=113,81 \cdot 10^{3} \mathrm{H} / \mathrm{M}\right)$ : 1 - 4,0 кB; 2 - 6,0 кB; 3 - 9,0 кВ

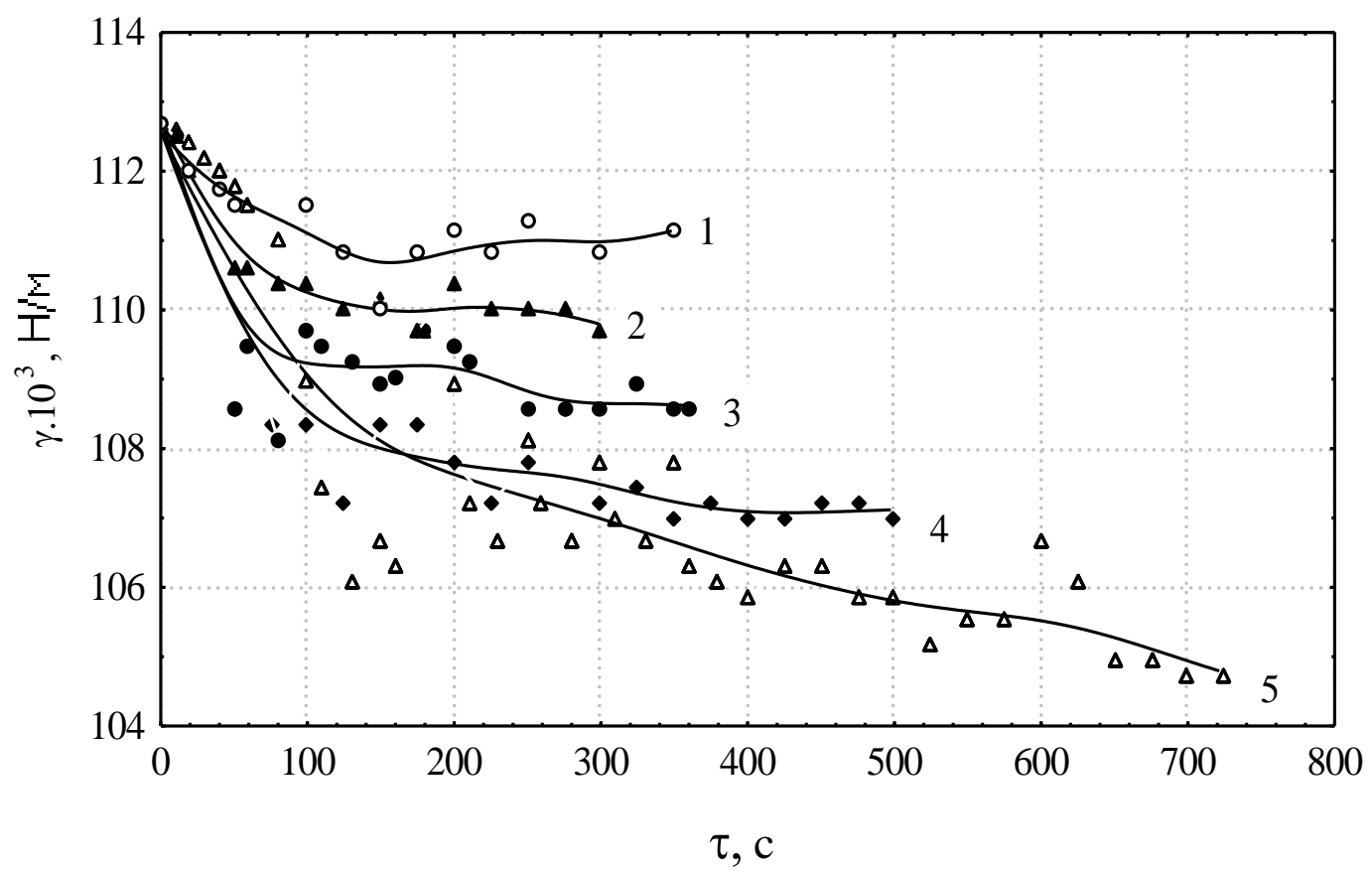

Рис. 10. Изменение поверхностного натяжения $\mathrm{KCI}-\mathrm{SrCI}_{2}\left(50\right.$ мол.\% $\left.\mathrm{SrCI}_{2}\right)$ во времени после ВИР при 1130 К $\left(\gamma_{0}=112,67 \cdot 10^{3} \mathrm{H} / \mathrm{M}\right)$ : 1 - 1,0 кB; 2 - 3,5 кB;3 - 6,2 кB; 4 - 8,8 кB; 5 - 10,5 кB 


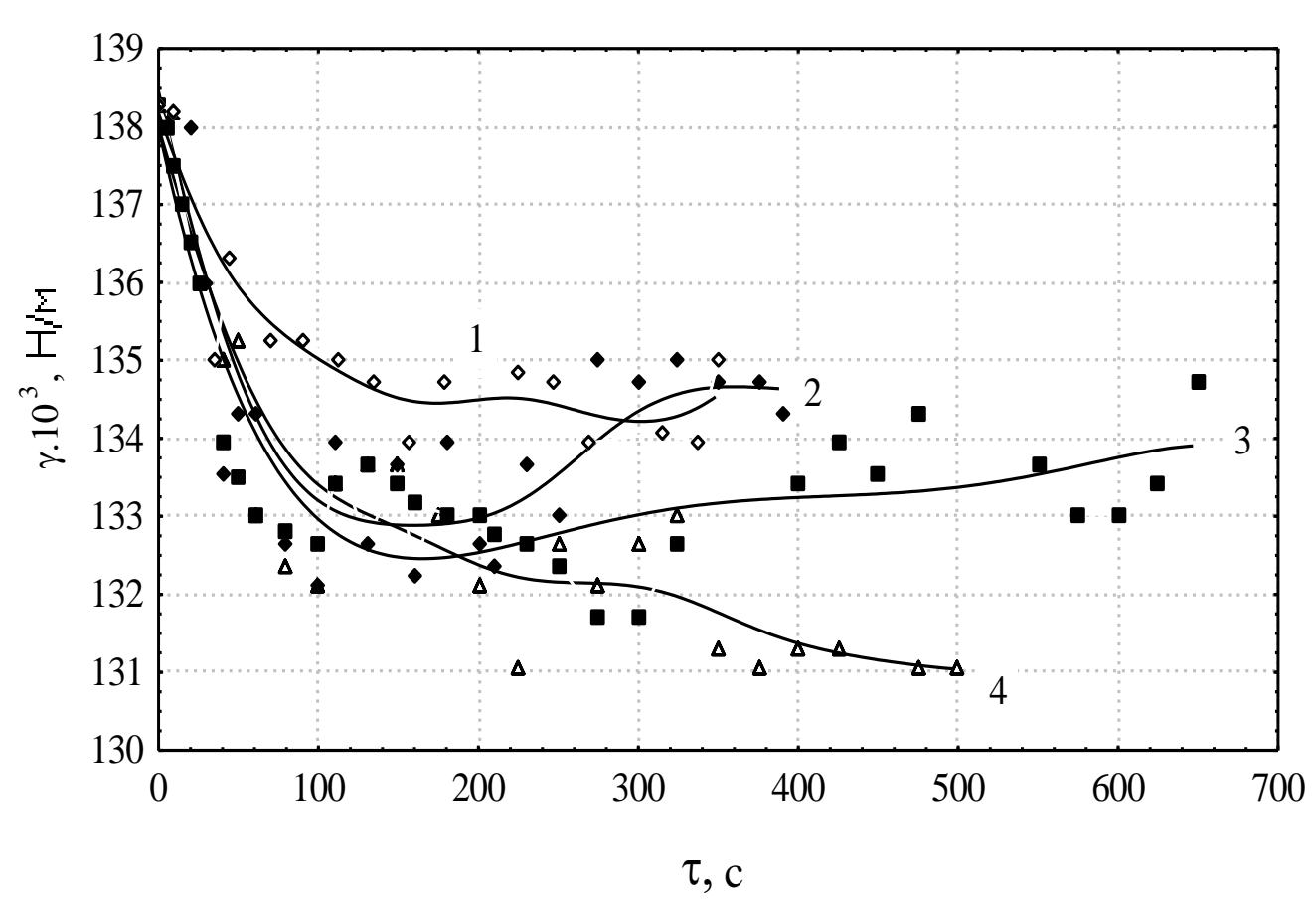

Рис. 11. Изменение поверхностного натяжения КCI-SrCI 2 (75 мол.\% $\left.\mathrm{SrCI}_{2}\right)$ во времени после ВИР при 1067 К $\left(\gamma_{0}=138,27 \cdot 10^{3} \mathrm{H} / \mathrm{M}\right)$ :

1 - 3,5 кB; 2 - 5,8 кB;3 - 7,5 кB; 4 - 10кВ

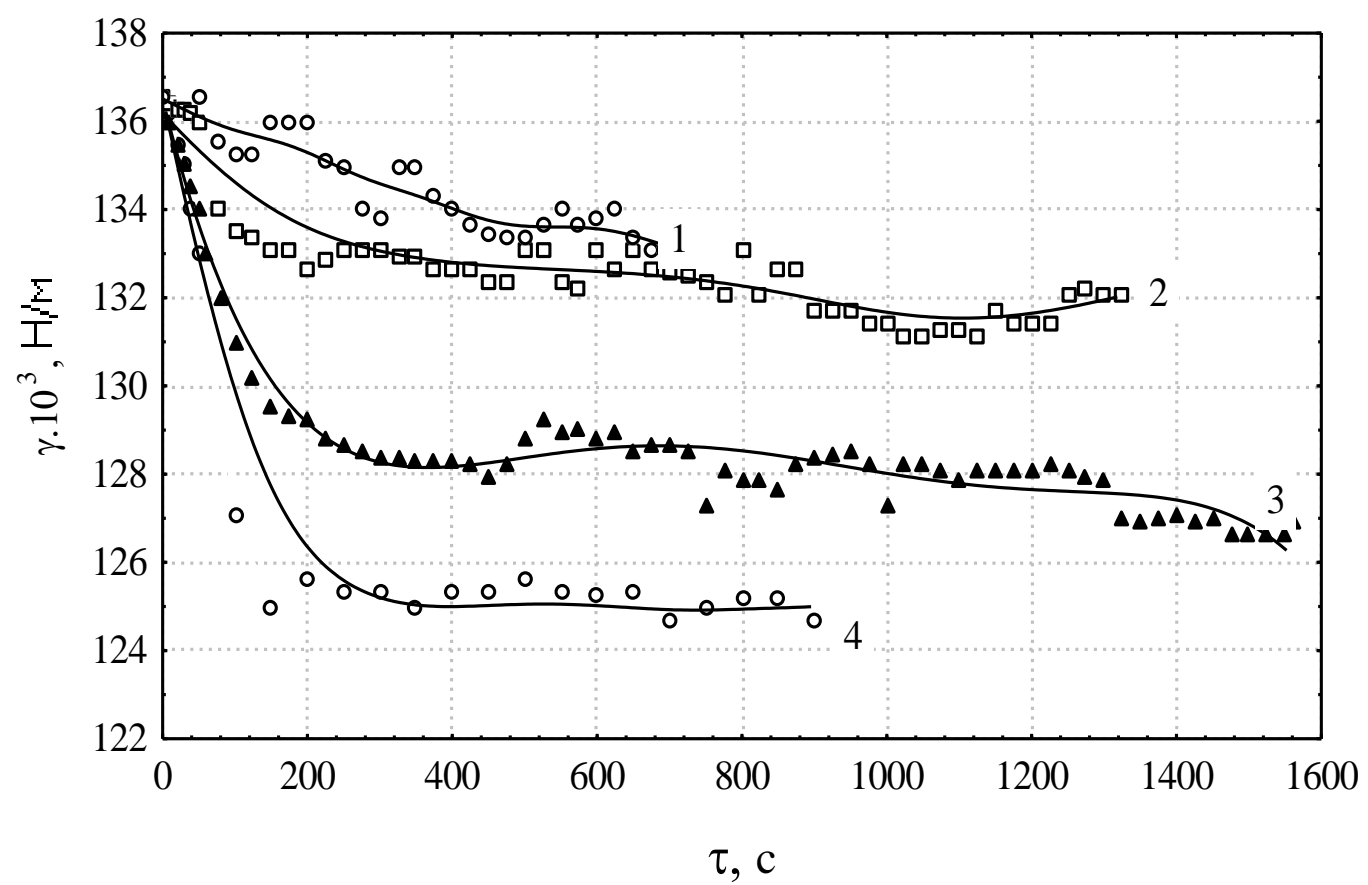

Рис. 12. Изменение поверхностного натяжения $\mathrm{KCI}-\mathrm{SrCI}_{2}\left(75\right.$ мол.\% $\left.\mathrm{SrCI}_{2}\right)$ во времени после ВИР при 1096 К $\left(\gamma_{0}=136,53 \cdot 10^{3} \mathrm{H} / \mathrm{M}\right)$ :

$$
1 \text { - 1,7 кB; } 2 \text { - 3,65 кB; 3 - 5,4 кB; 4 - 7,0 кB }
$$




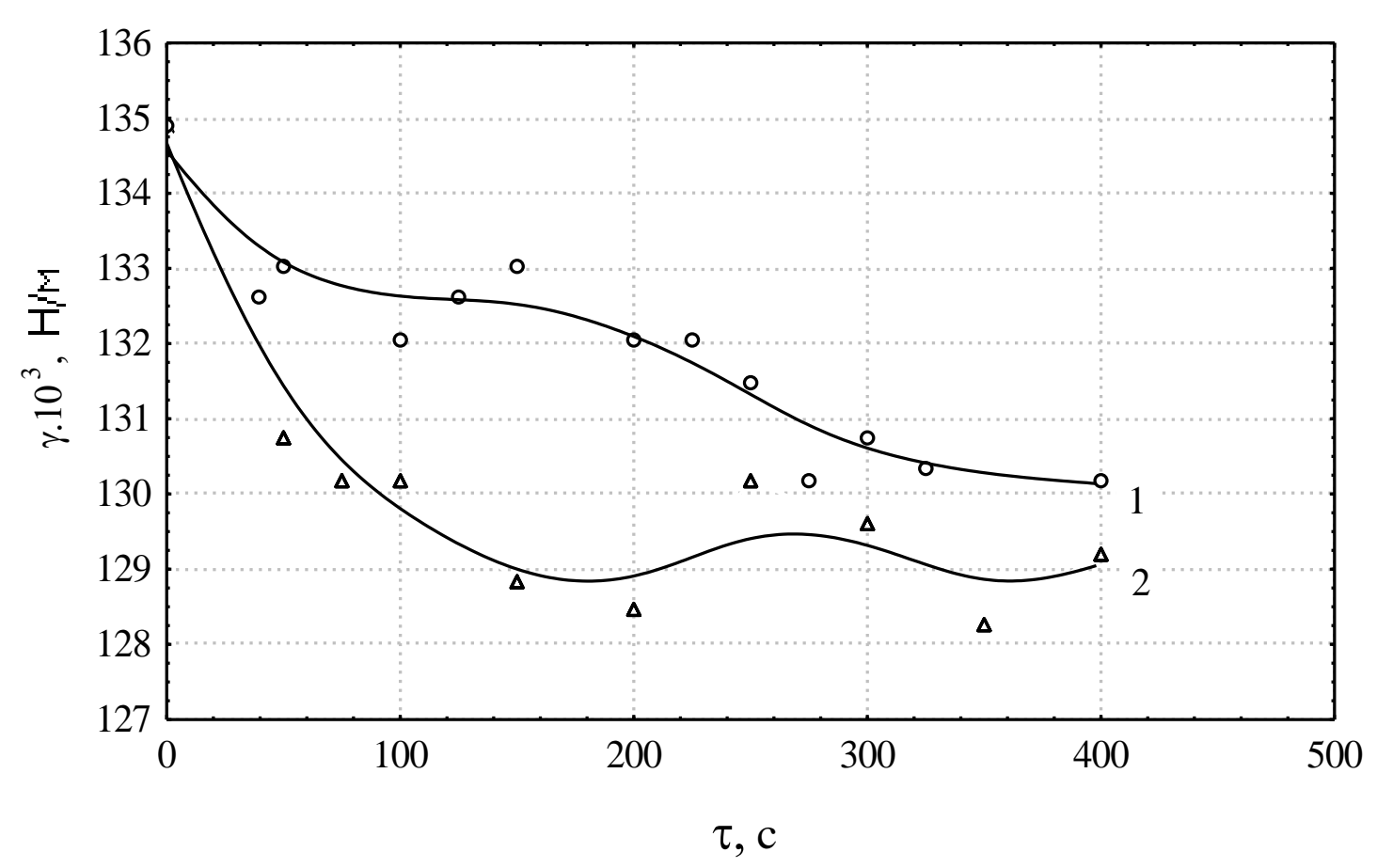

Рис. 13. Изменение поверхностного натяжения КCI-SrCI 2 (75 мол.\% $\left.\mathrm{SrCI}_{2}\right)$ во времени после ВИР при 1123 К $\left(\gamma_{0}=134,91 \cdot 10^{3} \mathrm{H} / \mathrm{M}\right): 1$ - 1,5 кВ; 2 - 3,2 кВ

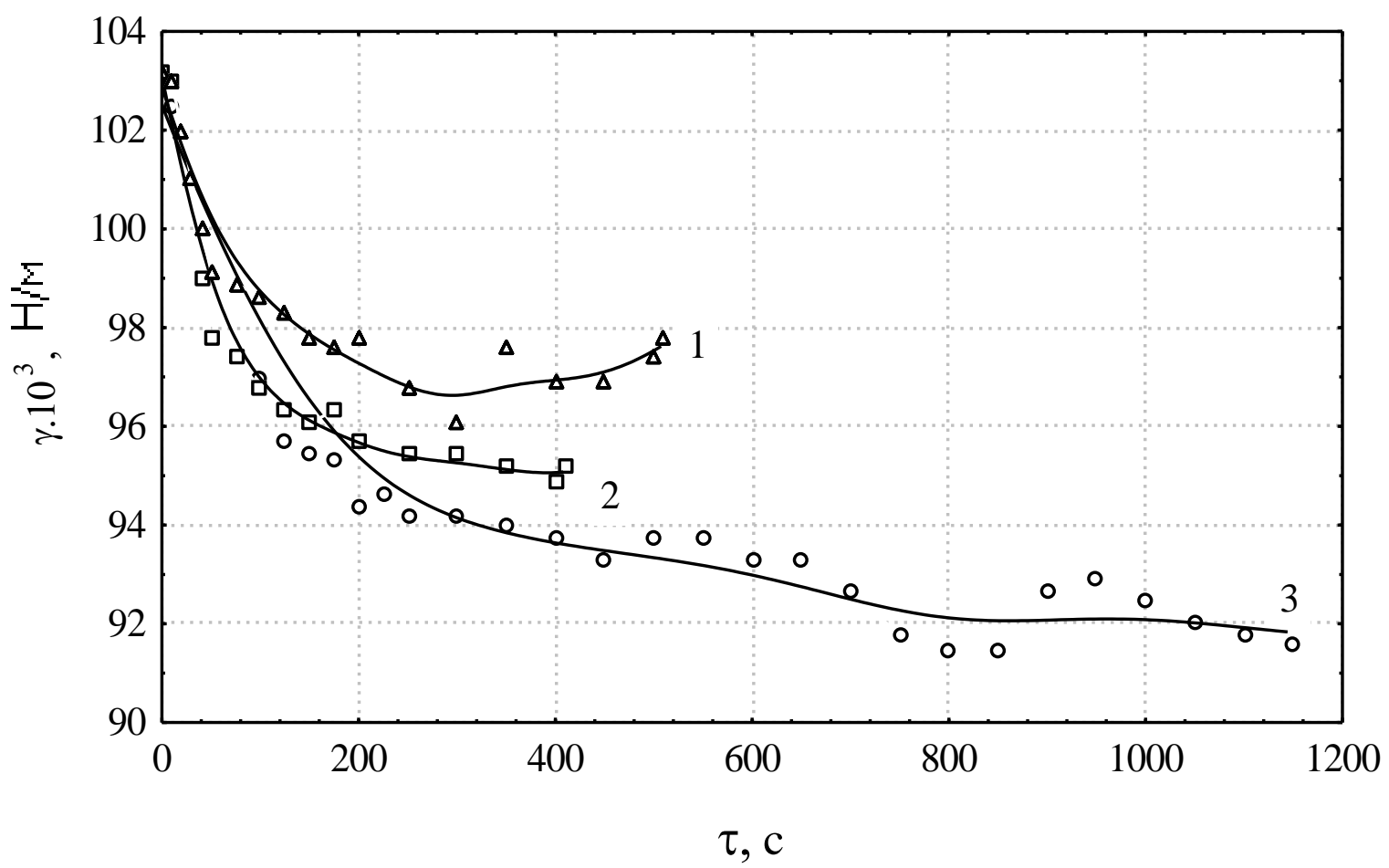

Рис. 14. Изменение поверхностного натяжения КСІ-ВаСІ 2 (25 мол.\% ВаСІ 2$)$ во времени после ВИР при 1123 К $\left(\gamma_{0}=103,17 \cdot 10^{3} \mathrm{H} / \mathrm{M}\right)$ :

$$
1 \text { - 3,0 кB; } 2 \text { - 7,5 кB; } 3 \text { - 8,5 кB }
$$




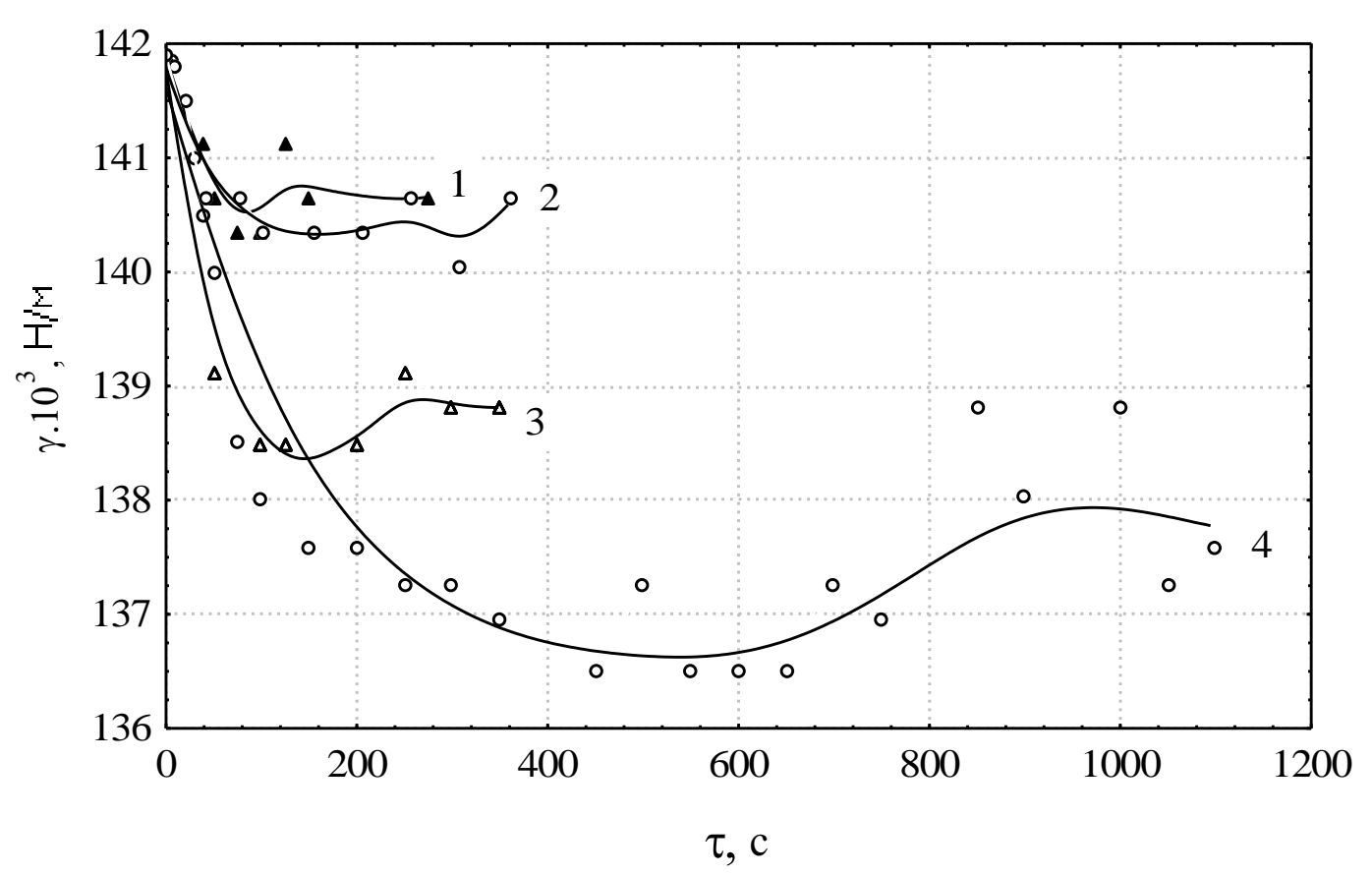

Рис. 15. Изменение поверхностного натяжения КСІ-ВаСІ 2 (50 мол.\% ВаСІ $\left._{2}\right)$ во времени после ВИР при 1052 К $\left(\gamma_{0}=141,89 \cdot 10^{3} \mathrm{H} / \mathrm{M}\right)$ :

$$
1 \text { - 3,0 кВ; } 2 \text { - 7,5 кВ; } 3 \text { - 8,5 кВ }
$$

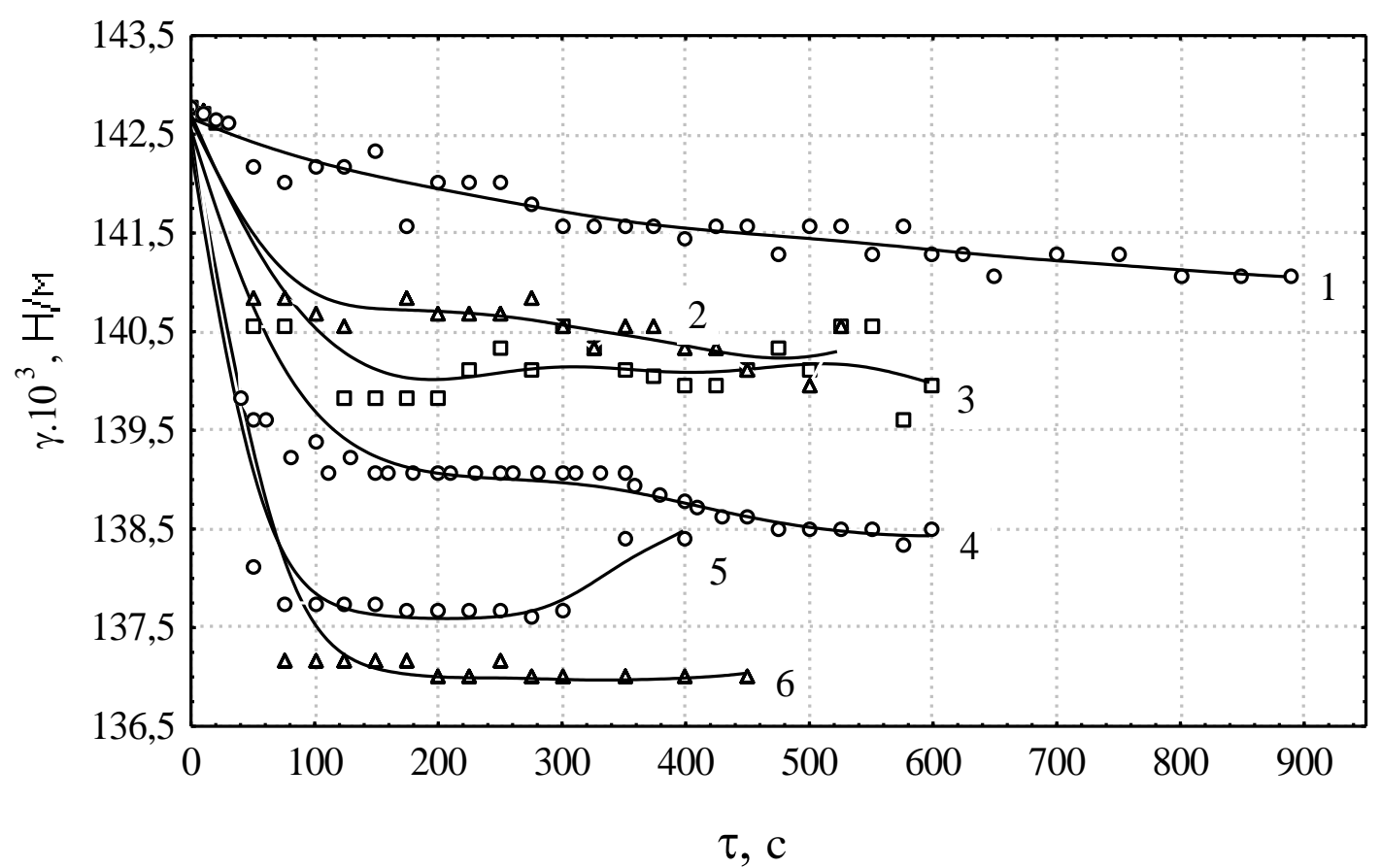

Рис. 16. Изменение поверхностного натяжения КСІ-ВаСІ 2 (75 мол.\% ВаСІ 2$)$ во времени после ВИР при 1038 К $\left(\gamma_{0}=142,76 \cdot 10^{3} \mathrm{H} / \mathrm{M}\right)$ : 1 - 1,5 кB; 2 - 3,0 кB; 3 - 5,4 кB; 4 - 6,3 кB; 5 - 7,1 кB; 6 - 8,0 кВ 
Из этих рисунков видно, что после подачи высоковольтных импульсов поверхностное натяжение, $\gamma$, уменьшается. Чем больше амплитуда импульсного напряжения, тем меньше $\gamma$ и тем больше относительное изменение коэффициента поверхностного натяжения. Причем, минимальное значение $\gamma$ после каждого импульса напряжения достигается через 4-8 минут.

Эксперименты показывают, что относительное изменение поверхностного натяжения $|\Delta \gamma / \gamma|$ увеличивается с ростом напряженности электрического поля и оно имеет тенденцию к насыщению. Наибольшее относительное изменение поверхностного натяжения (до $18 \%$ ) наблюдается в расплаве $\mathrm{KCl}-\mathrm{CaCl}_{2}$ эквимольного состава. Наибольшее относительное увеличение электропроводности (до 77 \%) также обнаружено в расплаве этого состава [5]. На рисунках 17-25 показана зависимость относительного изменения по абсолютной величине от амплитуды импульсного напряжения.

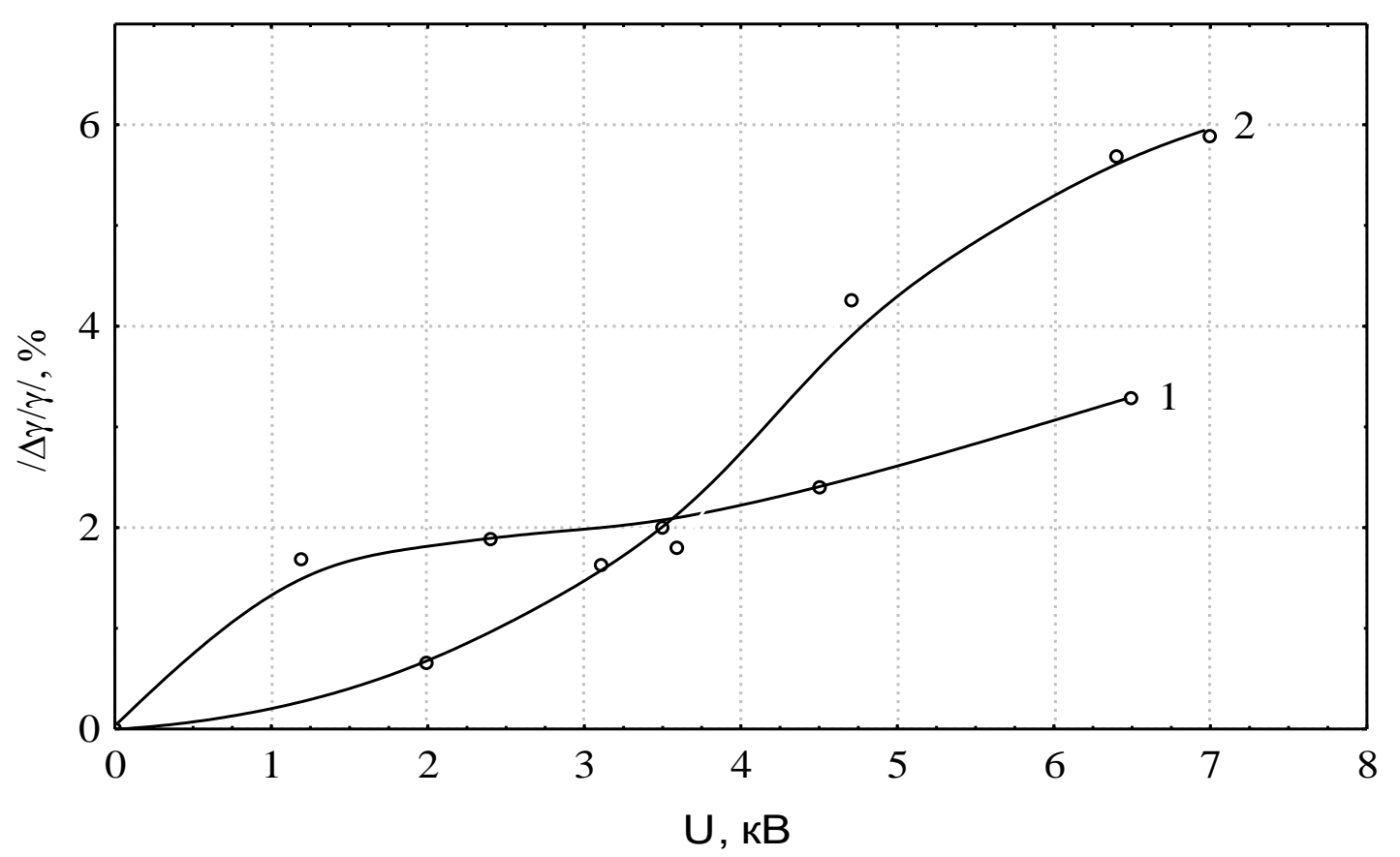

Рис. 17. Зависимость относительного уменьшения поверхностного натяжения КСІ-СаCI 2 (25 мол.\% СаCI $)$ от амплитуды импульсного напряжения при 1 - 1044 K; 2 - 1079 К 


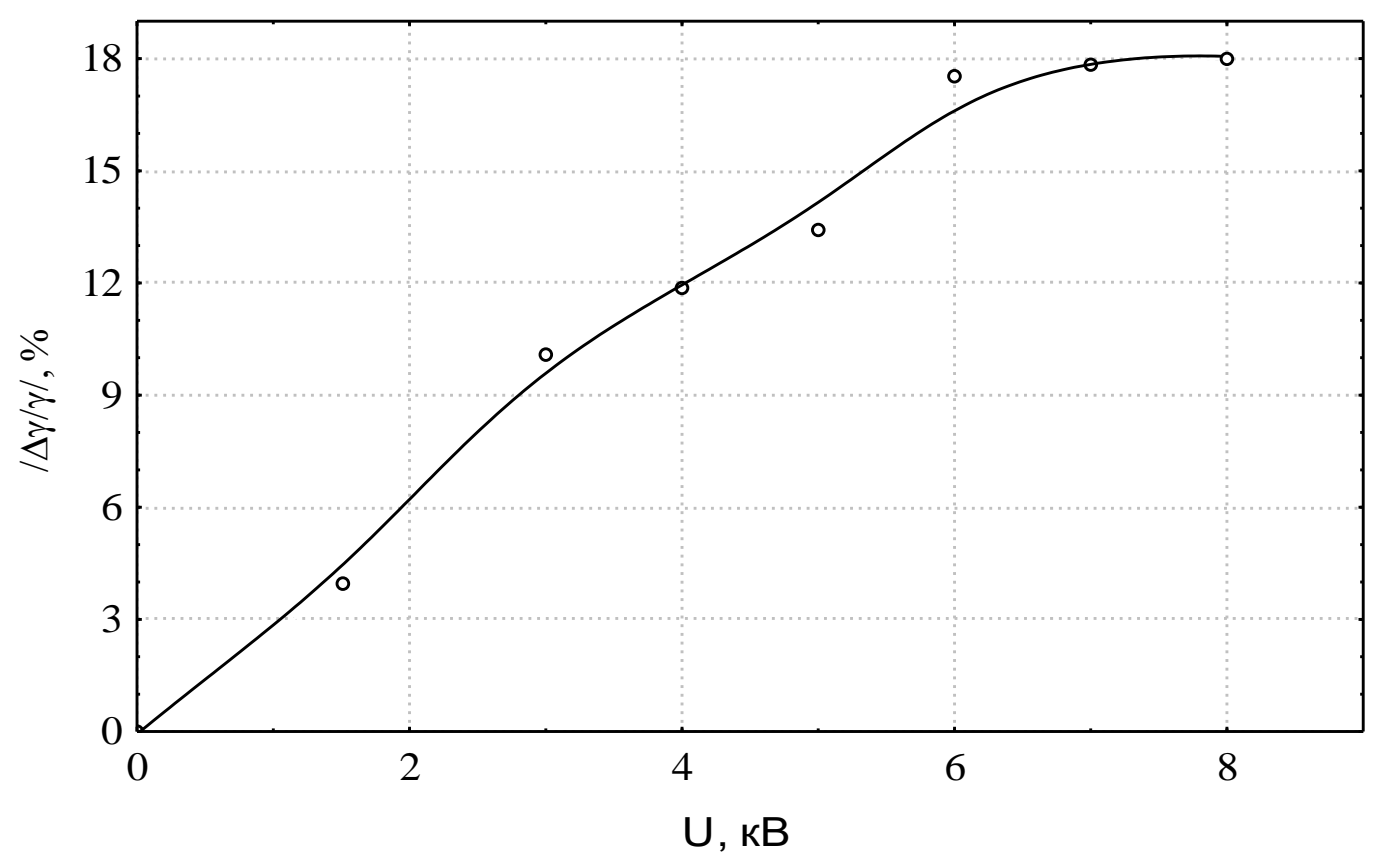

Рис. 18. Зависимость относительного уменышения поверхностного натяжения КСІ-СаCI 2 (50 мол.\% СаСІ 2 ) от амплитуды импульсного напряжения при $1115 \mathrm{~K}$

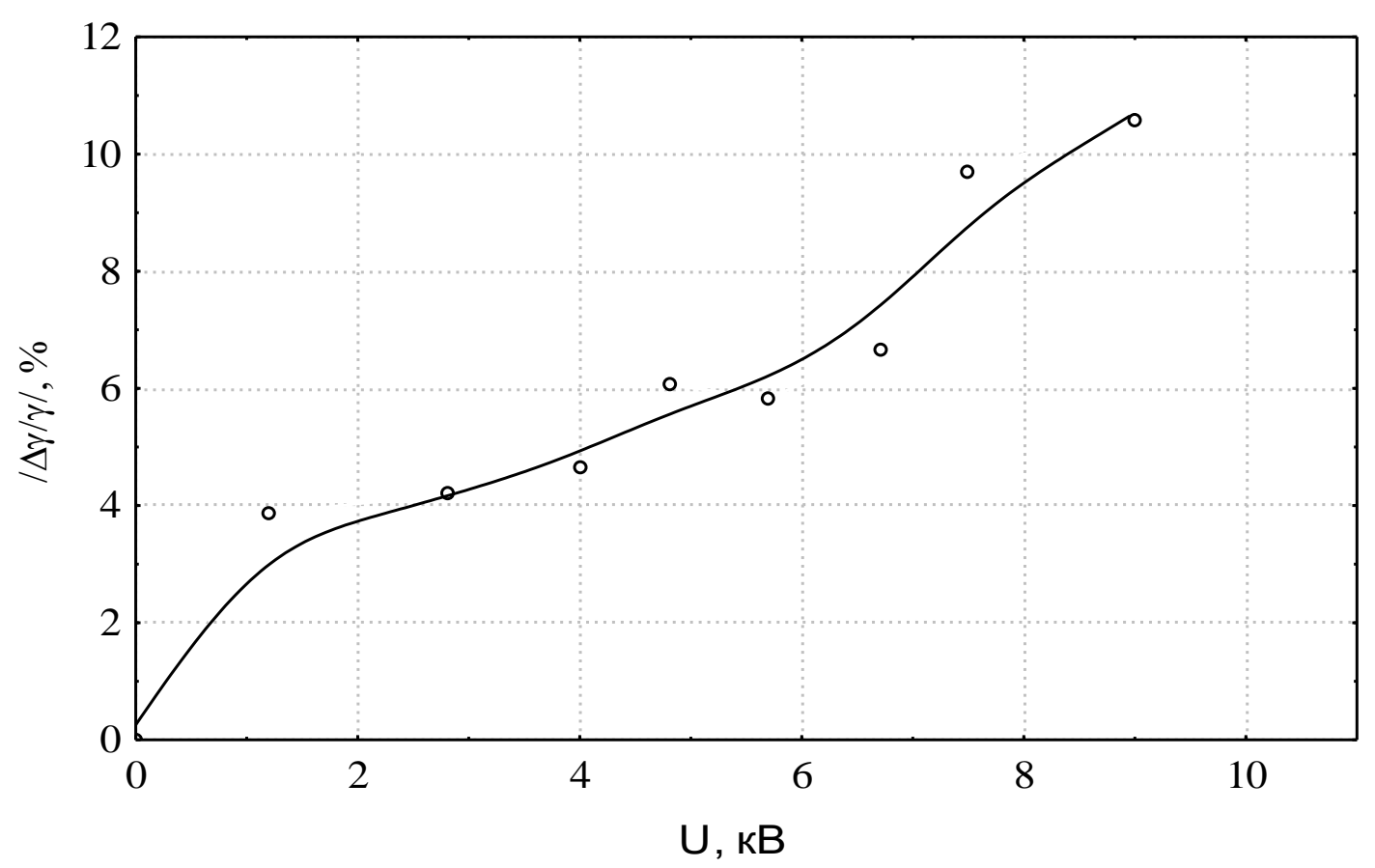

Рис. 19. Зависимость относительного уменьшения поверхностного натяжения КСІ-СаCI 2 (75 мол.\% СаСІ 2 ) от амплитуды импульсного напряжения при 1038К 


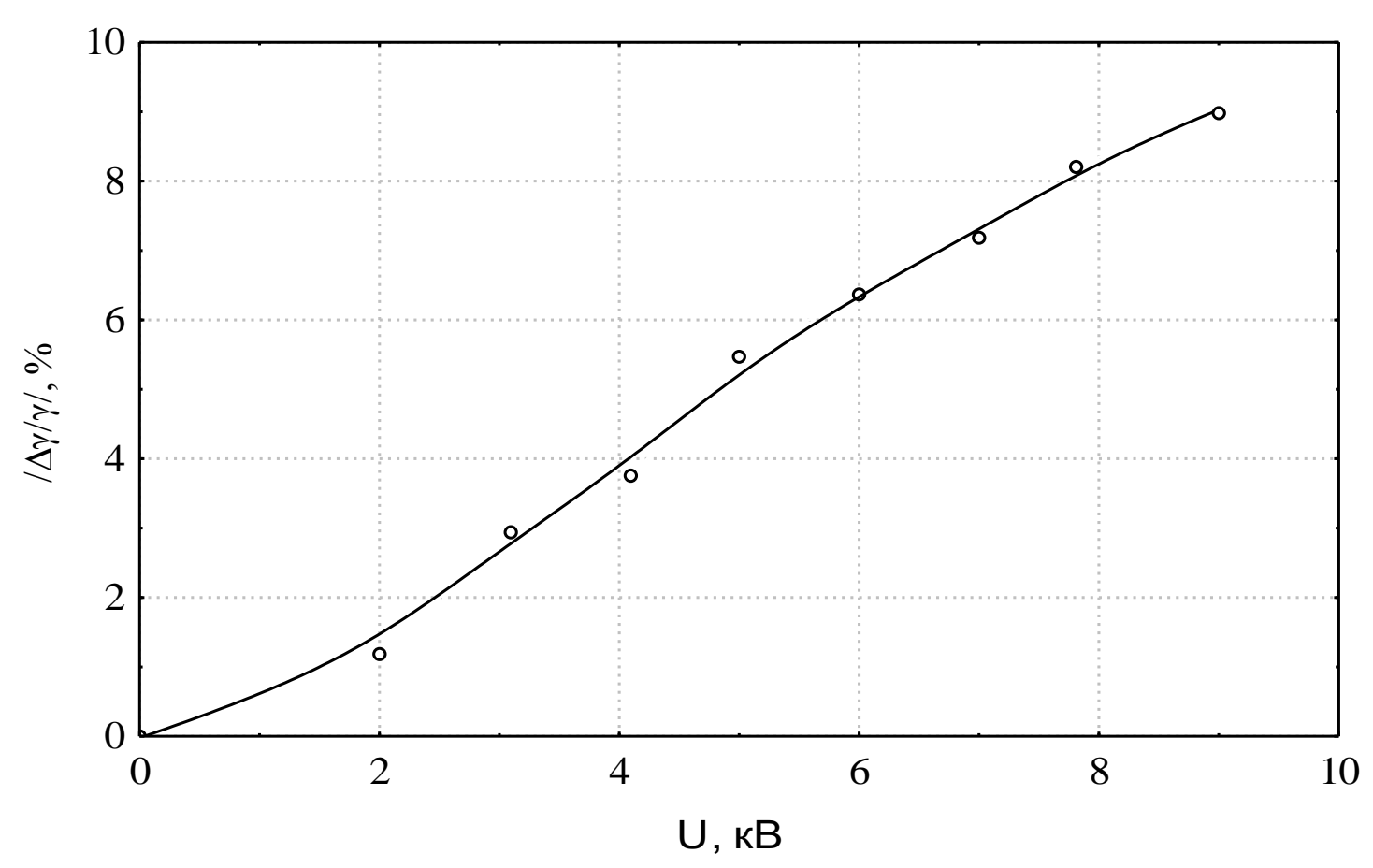

Рис. 20. Зависимость относительного уменышения поверхностного натяжения KCI-SrCI 2 (25 мол.\% $\left.\mathrm{SrCI}_{2}\right)$ от амплитуды импульсного напряжения при 968 K

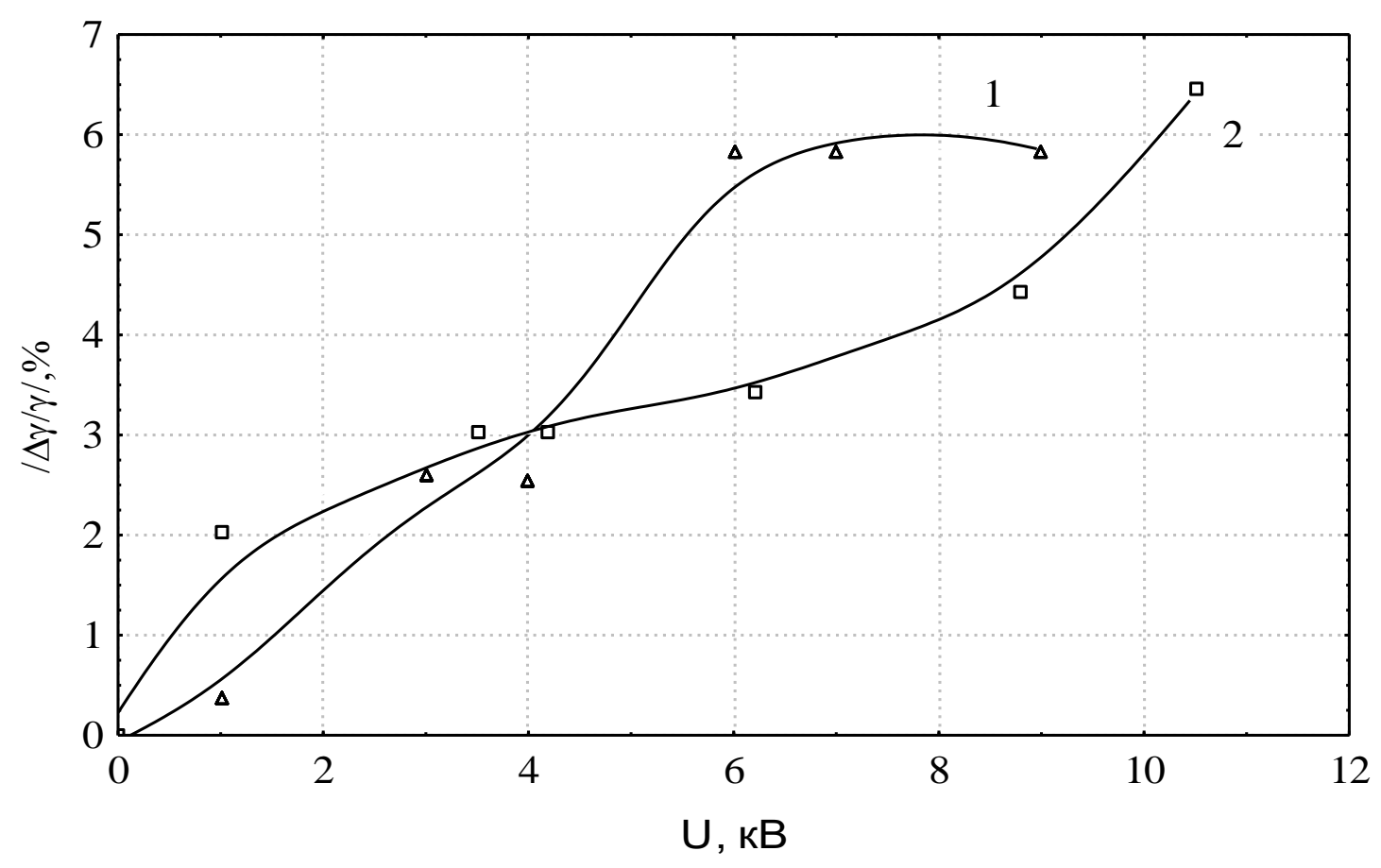

Рис. 21. Зависимость относительного уменышения поверхностного натяжения $\mathrm{KCI}-\mathrm{SrCI}_{2}$ (50 мол.\% $\left.\mathrm{SrCI}_{2}\right)$ от амплитуды импульсного напряжения при $1-1104$ К, 2 - 1130 К 


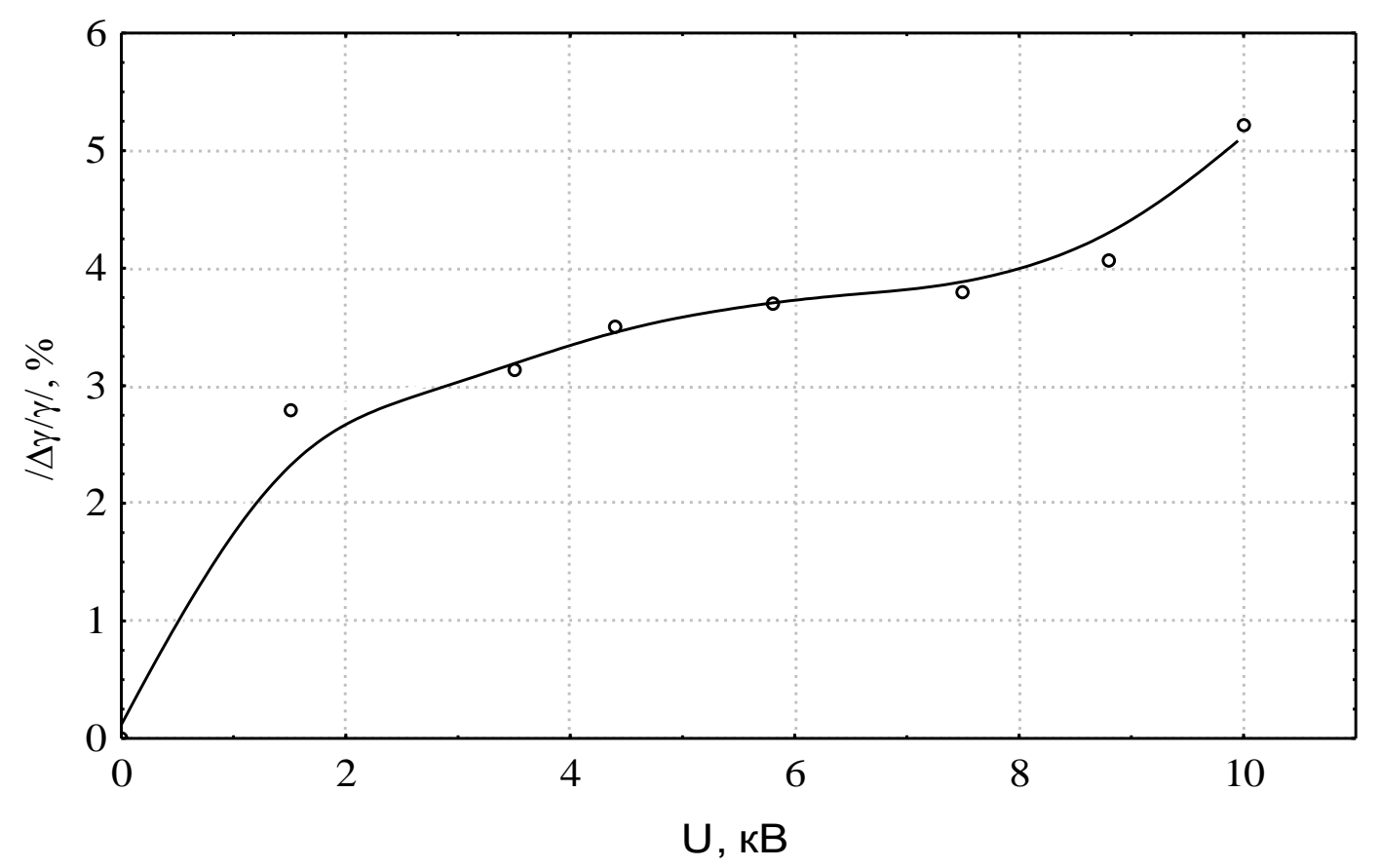

Рис. 22. Зависимость относительного уменьшения поверхностного натяжения KCI-SrCI 2 (75 мол.\% $\mathrm{SrCI}_{2}$ ) от амплитуды импульсного напряжения при 1067 K

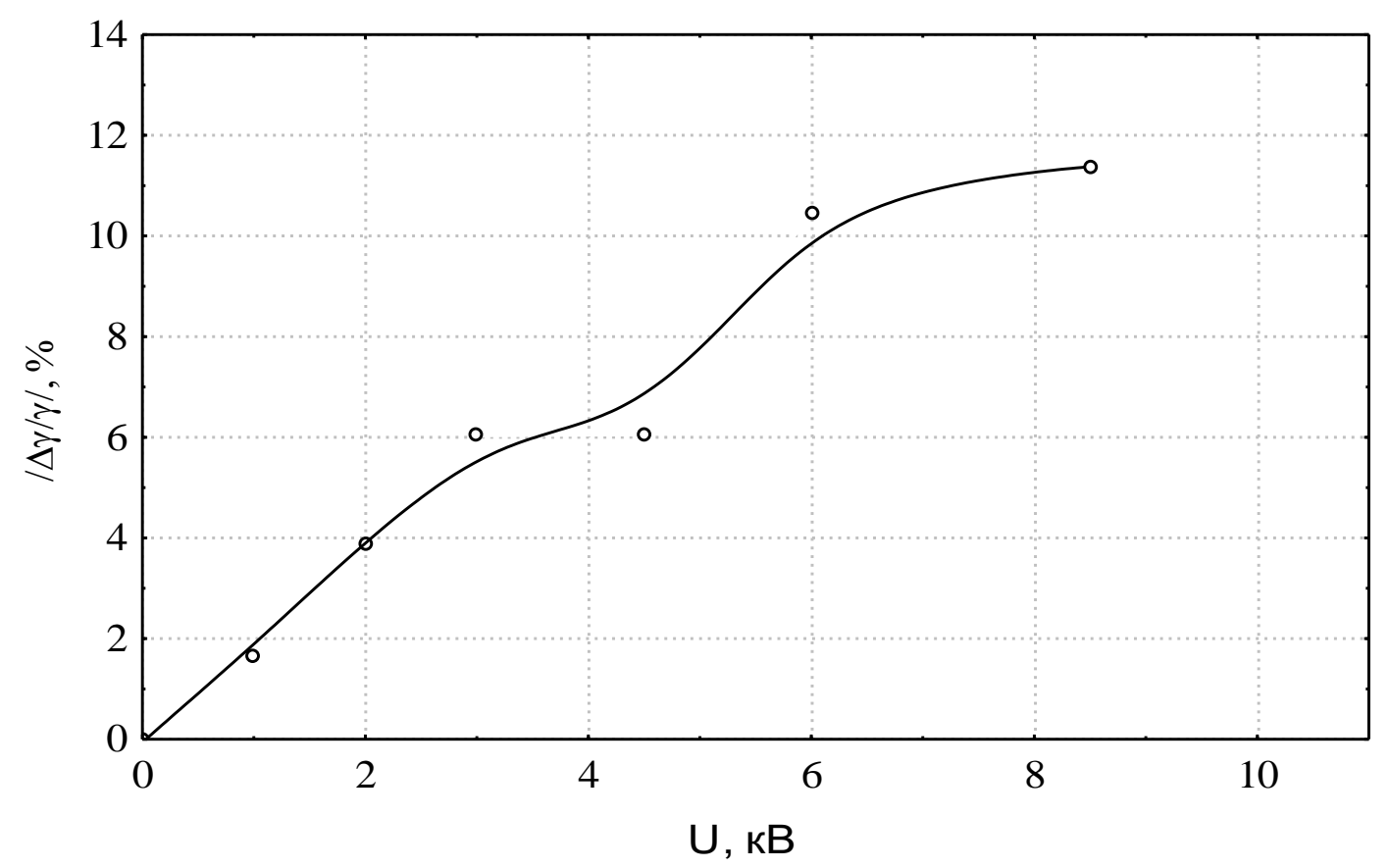

Рис. 23. Зависимость относительного уменышения поверхностного натяжения КСI-BaCI2 (25 мол.\% ВаСІ 2 ) от амплитуды импульсного напряжения при $1123 \mathrm{~K}$ 


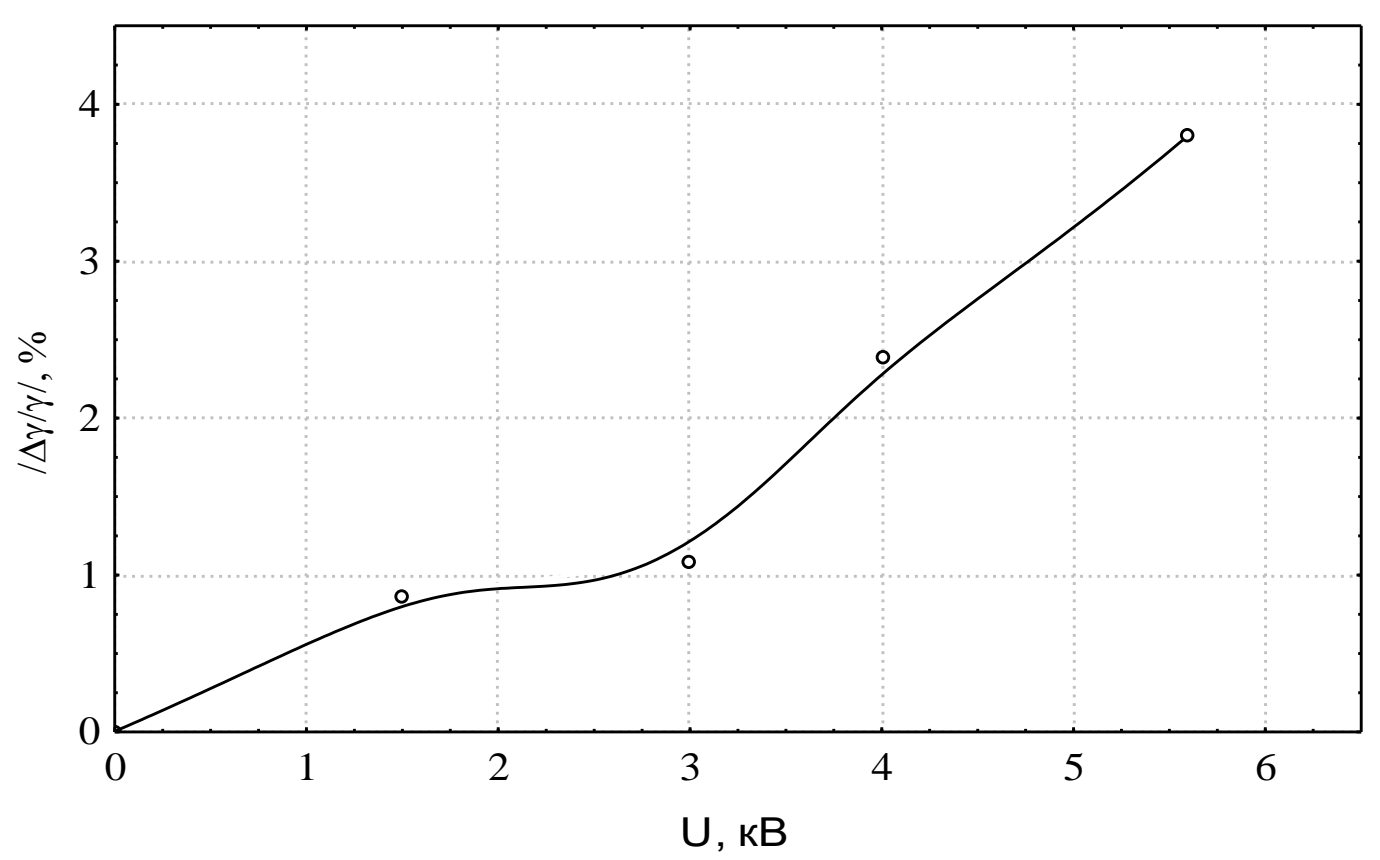

Рис. 24. Зависимость относительного уменышения поверхностного натяжения КСІ-ВаСІ 2 (50 мол.\% ВаСІ 2 ) от амплитуды импульсного напряжения при 1052 K

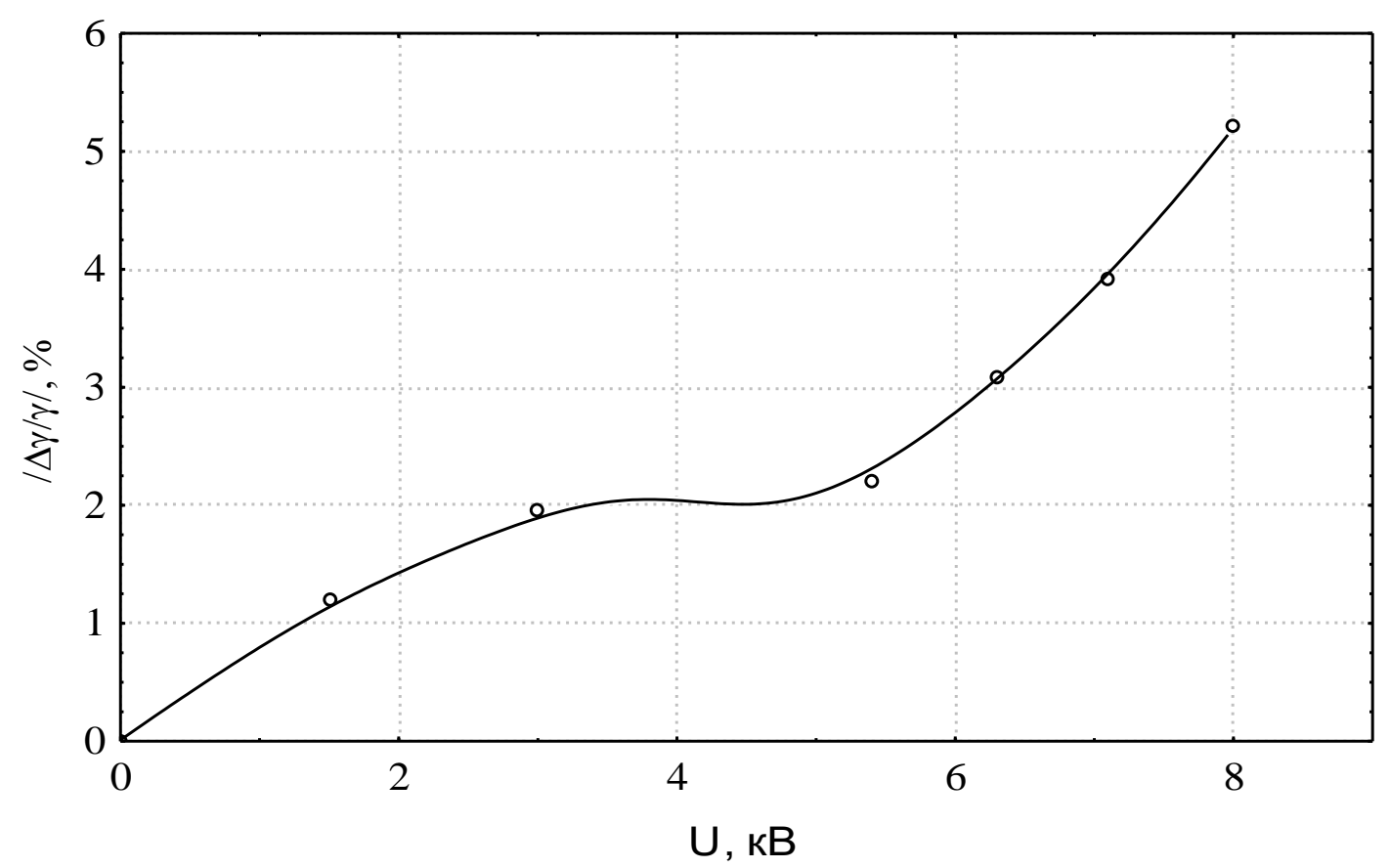

Рис. 25. Зависимость относительного уменьшения поверхностного натяжения КСІ-ВаСІ 2 (75 мол.\% ВаСІ 2 ) от амплитуды импульсного напряжения при $1038 \mathrm{~K}$ 
В таблице 1 также приведены исходные коэффициенты поверхностного натяжения $\gamma_{0}$, их значения $\gamma_{\text {E }}$ после высоковольтных импульсных разрядов в момент $\mathrm{t}=0$ и относительные изменения при достижении максимальных значений $\left|\Delta \gamma / \gamma_{0}\right|$ при исследованных температурах.

Таблица 1

Предельные значения поверхностного натяжения после ВИР

\begin{tabular}{|c|c|c|c|c|}
\hline Соль & $\mathrm{T}, \mathrm{K}$ & $\gamma_{0} \cdot 10^{3}, \mathrm{H} / \mathrm{M}$ & $\gamma_{\mathrm{E}} \cdot 10^{3}, \mathrm{H} / \mathrm{M}$ & $|\Delta \gamma / \gamma|, \%$ \\
\hline${\mathrm{KCI}-\mathrm{CaCI}_{2}}$ & 1044 & 129,0 & 124,7 & 3,3 \\
$\left(25 \% \mathrm{CaCI}_{2}\right)$ & 1079 & 125,2 & 117,8 & 5,9 \\
$\left(50 \% \mathrm{CaCI}_{2}\right)$ & 1115 & 109,8 & 90,0 & 18,0 \\
$\left(75 \% \mathrm{CaCI}_{2}\right)$ & 1038 & 107,2 & 95,86 & 10,6 \\
\hline $\mathrm{KCI}-\mathrm{SrCI}_{2}$ & & & & \\
$\left(25 \% \mathrm{SrCI}_{2}\right)$ & 968 & 113,16 & 102,97 & 6,0 \\
$\left(50 \% \mathrm{SrCI}_{2}\right)$ & 1130 & 111,96 & 104,74 & 5,25 \\
$\left(75 \% \mathrm{SrCI}_{2}\right)$ & 1067 & 138,27 & 131,06 & \\
\hline $\mathrm{KCI}^{-\mathrm{BaCI}_{2}}$ & & & & 11,36 \\
$\left(25 \% \mathrm{BaCI}_{2}\right)$ & 1123 & 103,17 & 91,61 & 3,80 \\
$\left(50 \% \mathrm{BaCI}_{2}\right)$ & 1052 & 141,89 & 136,49 & 5,22 \\
$\left(75 \% \mathrm{BaCI}_{2}\right)$ & 1038 & 142,76 & 137,01 & \\
\hline
\end{tabular}

Полученные экспериментальные результаты по влиянию ВИР на поверхностное натяжение солевых расплавов и постразрядовая его релаксация вполне логично объясняются комплексным строением. Согласно этой модели структуру расплавленных хлоридов щелочноземельных металлов можно представить как некоторую смесь комплексных и элементарных ионов:

$$
\frac{1}{n-1} M \mathrm{Cl}_{n}^{(n-2)-}+\frac{n-2}{n-1} \mathrm{MCl}^{+}+V^{0} .
$$

где $\mathrm{n}$ - первое координационное число, близкое к $4, \mathrm{~V}^{0}-$ вакансии нулевого заряда.

Разрушение комплексных группировок под влиянием ВИР приводит к уменьшению суммарной энергии этих группировок, а, следовательно, к уменьшению свободной поверхностной энергии, т.е. К уменьшению поверхностного натяжения. При рекомбинации структуры расплава к равновесному состоянию восстанавливается энергия связи частиц в комплексных группировках и $\gamma$ возвращается к исходному значению.

Задержка во времени достижения минимального значения $\gamma$ с момента подачи импульса, видимо, связано с тем, что процесс активации всего расплава, начиная с объема межэлектродного пространства, распространяется 
на весь объем. После достижения минимума $\gamma$ поверхностное натяжение начинает увеличиваться и стремится к исходному значению.

Время достижения исходного значения поверхностного натяжения довольно большое и по порядку величины равно времени релаксации проводимости расплавленных солей после высоковольтных импульсов $\left(\sim 10^{4}\right)$ [6].

Аналогичные закономерности в нитратах щелочных металлов, связанных с изменением структуры после высоковольтных разрядов, были обнаружены ранее [3].

Поверхностное натяжение проводящих жидкостей в электрическом поле уменьшается, и относительное уменьшение пропорционально квадрату напряженности электрического поля. Так как солевые расплавы обладают “памятью” электрического поля, то $\gamma$ должна уменьшаться. В активированных высоковольтными разрядами расплавах более подвижные катионы преимущественно могут быть адсорбированы на поверхности жидкости, что также приводит к уменьшению свободной поверхностной энергии.

\section{Список литературы}

1. Гаджиев С.М. Влияние высоковольтных импульсных разрядов на проводимость и процесс электролиза криолит-глиноземного расплава. Norwegian Journal of development of the International Science. Oslo. -2017. -№4.V.1. -P.18-20.

2. Гаджиев С.М. Высоковольтная проводимость промышленного магниевого электролита. Magyar Nudomanyos Journal. Budapest. -2017. -№ 2. P. 3-6.

3. Справочник по расплавленным солям, Химия, Ленинград. -1972. -2. $220 \mathrm{c}$.

4. Степанов В.П. Межфазные явления в ионных солевых расплавах. Екатеринбург: Наука.- 1993. - 315 с.

5.Гаджиев С.М., Шабанов О.М., Магомедова А.О., Джамалова С.А. Предельные высоковольтные электропроводности расплавленных смесей $\mathrm{KCl}$ $\mathrm{MCl}_{2}$ (M=Ca, Sr, Ba). //Электрохимия. -2003.-Т. 39.-№4. -С.425-430.

6. Шабанов О.М., Гаджиев С.М., Магомедова А.О., Гаджиев А.С. Высоковольтная активация расплавленных электролитов // Вестник. ДГУ. Естеств. науки. 1999.-№ 1.- С. 119-124.

(C) С.А. Джамалова, 2021 